Article

\title{
A HAZOP with MCDM Based Risk-Assessment Approach: Focusing on the Deviations with Economic/Health/Environmental Impacts in a Process Industry
}

\author{
Panagiotis K. Marhavilas* * , Michail Filippidis, Georgios K. Koulinas $₫$ and \\ Dimitrios E. Koulouriotis (D) \\ Department of Production and Management Engineering, Democritus-University of Thrace, 67132 Xanthi, \\ Greece; michalisfilippidis@gmail.com (M.F.); gkoulina@pme.duth.gr (G.K.K.); jimk@pme.duth.gr (D.E.K.) \\ * Correspondence: marhavil@pme.duth.gr
}

Received: 12 December 2019; Accepted: 28 January 2020; Published: 30 January 2020

Abstract: A joint-analysis by the use of (i) the multi-criteria decision-making (MCDM) technique of Typical-Analytical-Hierarchy-Process (T_AHP) and Fuzzy-Analytical-Hierarchy-Process (F_AHP) with (ii) the Hazard and Operability (HAZOP) method respectively, was conducted in a sour-crude-oil process industry (SCOPI), focusing on the deviations with economic/health/environmental impact. Consequently, the intention of this paper is dual; that means the first one is the presentation and application of the traditional HAZOP method on a SCOPI, and the second one the illustration and usage of the combined HAZOP_TAHP/FAHP framework in the previous referred industry, via the resulted hazards with economical, health and also environmental impacts, unveiling the sustainable dimension of this approach. The choice of the particular SCOPI for executing the HAZOP process is greatly powerful for the implementation of this approach, due to the plentiful hazards that the process includes, and due to its sophisticated design, as well. Originally, the conventional HAZOP study was carried out for finding out the potential destructive causes of abnormal circumstances in the SCOPI's establishment. Subsequently, the defined (by HAZOP) hazards with particular economic, health and environmental impacts were elaborated by the T_AHP and F_AHP techniques in order to broaden the HAZOP results and prioritize the risks in the worksite of the SCOPI. It is worthwhile mentioning that this joint-analysis can afford a reliable base to enhance procedure safety and upgrade the occupational health safety's level (OHS). Likewise, it might be a constructive means for the decision-makers to: (i) evaluate the urgent situation of the restricted resources' investment, in measures of preventing particular deviations (like the ones with economical, health and environmental consequences), and (ii) to endorse the sustainable growth of this industry, taking into account that a significant part of literature utilized the issue of sustainability as a frame for the development of OHS RAA techniques.

Keywords: crude-oil; sour gas; hydrogen sulfide; crude stabilization; hazard identification; HAZOP study; risk analysis; operability study; process safety; risk-matrix; DMRA; multi-criteria decision-making; Analytical-Hierarchy-Process; Typical-AHP; Fuzzy-AHP

\section{Introduction}

Although the chemical process industries (CPI) are among the safest workplaces in the world [1-3], mainly due to the severe procedures applied towards hazards, the public sense about them is that they are extremely hazardous with people fearing for their lives and/or health, and on the other hand, for their belongings and for the environment as well. Even so, throughout the last twenty years, the risk management and process safety actions were unfolded to a remarkable level, so that disasters 
like Flixborough (England, 1974), Seveso (Italy, 1976), Bhopal (India, 1984), Phillips (Pasadena/Texas, USA, 1989), AZF explosion (Toulouse/France, 2001) and Jilin (China, 2005) start to become lighter from memory. Above and beyond, a SCOPI can be greatly valuable for the local economies due to: (i) the work opportunities and (ii) the broad financial benefits it provides. Hence, even though there is always an existing likelihood for a catastrophe commencing, on the other side, disasters could be eliminated by proper risk management.

The Hazard and Operability analysis (abbreviated as HAZOP) emerged with the purpose of recognizing potential hazards in establishments that operate using extremely harmful materials. The major care was to abolish every source that can probably lead to a serious accident, such as explosions, fires and toxic-release [4]. Nevertheless, with the passage of time, HAZOP's handling was expanded to various other kinds of services because of its capability, not only to recognize hazards, but also to identify functional deviations from the preferred state. Thus, HAZOP technique has been chosen, among other actions, for road safety actions [5], hazard identification in photovoltaic installations [6], and diagnostic systems in medicine [7]. The miscellany of fields, that used HAZOP, shows that this methodology has been constituted as a dominant technique to meliorate numerous types of systems.

On the other hand, the Analytical-Hierarchy-Process (AHP), introduced by [8] was recognized as one of the more frequently used and proficient multi-criteria decision-making methods. Many applications (which employed AHP) were used for assessing health and safety risk factors such as the pioneer study of Henderson and Dutta (1992) [9], in which ergonomic factors were assessed. Other interesting applications were the multi-criteria-based occupational health safety (OHS) risk-evaluation method proposed by Badri et al. (2012) [10] and the study of Aminbakhsh et al. (2013) [11] which employed Typical-AHP (T_AHP) for assigning priorities to safety risks in construction sites.

Over and above, one of the highly significant features of risk management is the hazard identification, while a significant means is the HAZOP method. According to Mayes and Kilsby (1989) [12], HAZOP is a greatly versatile technique for hazards' identification in the chemical engineering industry, and has been confirmed, over the years, to be one of the most essential tools in order to ensure: (i) the safety of the employees in a plant, (ii) the environment, and naturally (iii) the probity of the facility itself [2]. Besides, taking into account that HAZOP's major intention is hazards' identification, it is assumed as the most excellent PHA technique of producing data for consequent quantitative-analysis techniques like QRA or FTA $[2,13]$. What is more, as the motivation for all industries (and the same for a SCOPI) is the turnover's raise, HAZOP analysis has additionally the considerable potentiality of identifying (i) not only the hazards for health and safety, but in addition (ii) the functional establishment's troubles, and (iii) the deviations with economic and environmental impacts, as well.

Nonetheless, although being efficient and well-organized for hazards' identification and risk-ranking in hazardous systems, HAZOP has its weaknesses; it is susceptible to ambiguous decisions, and, additionally, it has a variety of restrictions, like the subsequent: (a) it considers equivalent weights for the risk-factors (i.e., "low-probability/high-consequence" and "high-probability/low-consequence" hazards are approximately equivalent as far as the risk-ranking is concerned), and (ii) it utilizes accurate data, which are seldom available, particularly in the SCOPI's establishments [14,15].

On the other hand, risk prioritization (by T_AHP and F_AHP) can certainly help a manager: (i) to define the most urgent risk factors and implement the most significant safety measures, in order to attain the best allotment of a limited budget in risk-diminishing projects, and (ii) to degrade and/or eradicate the most critical risk-deviations (determined by HAZOP) with economic/health/environmental impacts by fulfilling the most imperative safety measures. In other words, improved distribution of the constricted funds: (a) can decrease support and financial costs, and (b) can normally allow managers to have available resources for further risk-diminishing in the enterprise [16,17].

This work concentrates (i) on an extensive HAZOP methodology with the DMRA tool (i.e., decision-matrix risk-assessment), combined with the Typical-Analytical-Hierarchy-Process 
(T_AHP) and also with the Fuzzy-Analytical-Hierarchy-Process (F_AHP), and (ii) on the jointed HAZOP_TAHP/FAHP approach, executed as a case study in a SCOPI's establishment. Accordingly, the paper's intentions are the following: (i) the presentation and application of the HAZOP process in a specific SCOPI, (ii) the execution of the combined HAZOP_TAHP/FAHP framework on this SCOPI (focusing on the defined hazards that have economic, health and environmental impact), and additionally (iii) to disclose that the proposed HAZOP_TAHP/FAHP scheme can be a valuable technique for the decision-makers to meliorate OHS and process safety, and also to support the sustainable-operation of this SCOPI, given that a considerable part of literature utilized the matter of sustainability as a frame for the progress of OHS-RAA techniques [18].

In particular, the pathway toward accomplishing the sustainable development targets in a corporation, is achieved by intensifying amalgamation among different fields, and is associated with various key topics, like: (i) sustainable environment (that concerns the dynamics between human activities and ecosystem, including energy, chemistry, climate change, etc.), (ii) sustainable living (that means the achievement of health, carbon neutral and zero waste communities, including among other aspects, industrial production and consumption, buildings and infrastructure, supply chain and transportation, etc.), and (iii) sustainable technology (i.e., technologies that improve sustainability in all aspects) [19] (ICST\&D, 2019).

Principally, a separate technique could not accomplish the best RAA performance in the industries' workplaces, and consequently, the development of an integrated RAA technique, which will combine a well-considered selection of comprehensive techniques (like HAZOP, DMRA, T_AHP, F_AHP, etc.) would allow industries (by the joint-analysis) to attain significant results in risk assessment [20-22].

The paper is structured by the subsequent parts: (1) introduction, (2) theoretical background, which concentrates on the conventional HAZOP method, on the DMRA risk-ranking technique and on the T_AHP/F_AHP processes, (3) the technical illustration of a particular sour-crude-oil process industry (SCOPI), (4) the development of the proposed HAZOP_TAHP/FAHP approach and its application, as a case study, on the precise SCOPI, and (5) the discussion of the foremost points and conclusions.

\section{Theoretical Background}

\subsection{The Hazard and Operability (HAZOP) Procedure}

HAZOP study was introduced, in the decade of 1960, through the "crucial examination" procedure of ICI (the Imperial Chemical Industries); while a decade afterward it was officially published as a restricted procedure for defining deviations from the design target. More explicitly, the HOC/ICI (Heavy Organic Chemicals) tried to design a construction for producing acetone and phenol from cumene, and so that, the responsible management team identified hazards or deviations from the normal operation. Thus, the HAZOP process (or another one similar to the current standardized method) appeared.

Furthermore, Lawley, in his interesting article of 1974, described the required principles to accomplish HAZOP analysis/studies due to the rising difficulty of the novel technique that might not be comprehensively explained by the normal standards [23,24], while the first primary directions concerning HAZOP were published in 1977 [25], and thus, it was recommended as a method to be applied in the process industries in order to recognize hazards and prepare safety actions.

The most important issue of the HAZOP technique is the detection of such design features that are susceptible to deviations which may result in a state of affairs within the study's intentions or aims. Normally, the design goal for a process is composite with some features that are subtle and its description is demanding, and on the other hand, the HAZOP study's team frequently identifies the design's goal plainly by choosing process factors from a checklist with no complete consideration of all key features of the design's goal [26]. To continue, Markowski and Siuta (2018) [27] developed a fuzzy-relied HAZOP for PHA of LNG storage services, where various indices are set up for managing the study's effectiveness and its quality as well. A widespread literature review for HAZOP technique 
has been recently incorporated in the work of Marhavilas et al. (2019) [2], while in the review of RAA techniques by Dallat et al. (2019) [28], some HAZOP derivatives are additionally referred.

Despite its usefulness, the HAZOP study has its own weakness and it shares limitations with other process hazard-analysis techniques [29]. More explicitly, Baybutt [29] presents a detailed critique wherein restrictions of HAZOP coming from the people executing the HAZOP study, in association with the deviations, the initiating events, the design intent, the technical coverage, the guide words, and the documentation, are discussed exhaustively. Moreover, Sultana et al. (2019) [3] notice that complex systems could not be suitably analyzed by conventional hazard-analysis tools (like the HAZOP one) and/or plain reliability-analysis techniques (like the FMEA one), so other techniques, such as the systematic hazard-analysis technique of STPA (System Theoretical Process Analysis) can be complementary to conventional HAZOP.

Recently, Animah and Shafiee (2020) [30] in their analysis exemplify several of the HAZOP's advantages (like its helpfulness in cases of risks which are complicated to be quantified in the LNG sector), and on the other hand, the disadvantages (like its incapability to appraise the risks appeared in a multi-component system, wherein diverse parts interrelate with each other).

The HAZOP technique needs the joint efforts of a team that is responsible for the system's management and is separated into the next stages: preparation, organizing, and execution/documentation [31,32].

Several factors are taken into consideration for the proper preparation of the HAZOP process, and the specification of its steps, like the consequent of the interrogative words: "how", "why", "where", "when", and "who" [32-35].

HAZOP technique cannot be performed at the conceptual stage of a project, due to the lack of any comprehensive P\&ID, i.e., any "Piping and Instrumentation Diagram" at that moment. A hazard appraisal has to be achieved for identifying possible hazards existing in the process. Through the design phase, wherein its basic concept is entirely defined, the P\&IDs are becoming available in order to provide adequate information for the deviations' investigation step of the study. In addition, HAZOP process is an extra handy process for accomplishing a comprehensive appraisal, earlier than installations' commencement [25].

Initially, HAZOP was considered appropriate only for new installations, but shortly after, was recognized as a valuable tool for existing establishments as well, because of the introduction of new regulations (such as SEVESO-directive), which require the performing of a periodic hazard-analysis in a facility, and due to the increasing safety-consciousness in industry. The possible hazards in an existing establishment cannot be calculated or recognized at the commencement of its functioning because the elaborated processes could change noticeably over time. In the case that a hazard might be present in the process, the existing HAZOP process should be revised, according to Baybutt (2013) [36]. Taking into account the article of Frank and Whittle (2001) [37], three types of HAZOP revalidation exist, such as, support, revision and replacement.

The study's definition has an evident consequence on the analysis's content, and also settles the criteria that the team's leader will use in order to gather the team-experts for conducting the HAZOP P-study. The project-leader in collaboration with the HAZOP's team-leader will determine the two key-topics of the process; initially, the details of its intention (i.e., why the study is performed), scope (i.e., what is included in the study) and objectives (i.e., what is to be considered), and secondarily, the efficient HAZOP team to realize the specific objectives (more information in the guidelines for defining HAZOP studies, by CCPS (1995)) [38].

Furthermore, the study's scope will comprise the whole equipment/tools which are used in the installation. Eventually, the intentions must always contain the identification of hazards in the establishment and the possible operating troubles. The hazards, according to Qureshi, can be safety/health and/or environmental ones, which might come from, or create an impact, both on- and off-site [39].

There are various types of hazards in a variety of installations that the HAZOP process might take place (for instance, fire, explosion, physical explosions, chemical explosions, toxic release, reactivity, 
etc.). Several of the potential hazards which must be recognized, particularly in process-installations that manage exceedingly hazardous materials, have been published by CCPS [40] in a catalog. This one constitutes a guidelines-list of the objectives as they are the hazards that need to be determined in the HAZOP analysis [41].

A HAZOP team involving: (a) more than seven (7) members, is not creative enough (mainly, due to communication problems), and (b) fewer than five (5) members, typically does not cover the essential knowledge-field for ensuring the execution of a thorough study. Consequently, the best size for the HAZOP's team must be equal to five, six or seven members [42].

The HAZOP analysis is a structured technique of defining forthcoming hazards. Hence, one critical point for the success of the effort is the study's planning into manageable parts, suitable for analyzing. The appropriate partition into nodes, with the right sizes, is a complicated job, so the practice can be considered as a subject of an art, due to the fact there is no aided node-management, but on the other hand, it relies completely on the judgment of the HAZOP team leader [43].

Chemical processes incorporate a broad range of interrelated components and auxiliary devices to implement the establishment's design intention (for instance, the crude-oil stabilization), so the equipment splitting into various nodes could be thorny due to their interconnectivity in the specific process industry. Thus, there are two views, which the HAZOP team's leader has to consider, when he decides the selection of the nodes, i.e., the node-parts ought to be equivalent as far as the size is concerned, and the involved equipment of a node ought to share the similar design and aim [2].

The members of the HAZOP team can recognize hazards that originate from various situations, such as: (a) deviations, that influence more than one-node (for instance a "flooding", or an "electric-power failure"), (b) situations, which also influence more than one-node (like "human factors", "piping and vessel physical configuration" and others), and (c) multiple-failure scenarios [42].

The HAZOP execution sub-stage of the study, associated with a division of the system into nodes, with particular interconnectivity and operation, follows the arrangement of nodes. The method is relied on the handling of specific guidewords, like the subsequent: (i) "No", (ii) "More" and (iii) "Less", in amalgamation with a variety of parameters, like the following: (i) "Flow" (ii) "Pressure" and (iii) "Temperature", in order to generate deviations from the regular functioning. The HAZOP team investigates the potential hazards of a node and proceeds to the identification of specific causes or/and consequences, constituting a scenario with safeguards which can detect/prevent and control/alleviate the hazardous circumstances. Ultimately, when the safeguards are inadequate to appropriately manipulate the specific problem, subsequently, the HAZOP team's members will be obliged to give its advices [41].

Even though, HAZOP process "knows" how to adapt the diverse requirements, there are some critical and most frequently used guidewords [44], as follows:

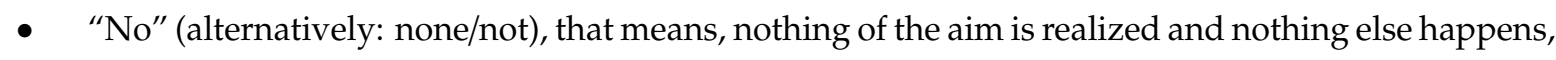
as well.

- "More" (alternatively: more of/higher), that means, the design's target is accomplished in such a way which is quantitatively greater.

- "Less" (alternatively: less of/lower), that means, the design's target is implemented by a quantitative reduce of the parameter it is associated to.

- "As well as", that means, the design's aim is succeeded in parallel with something else (e.g., an extra action).

- "Part of", that means, the design's aims are achieved, only partially.

- "Reverse", that means, the logical opposite of the design's goals really happens.

- "Other than", that means, nothing of the intent is realized, and on the other hand, something entirely unusual happens.

The combination of these guidewords with process factors (or parameters) defines particular deviations from the design's goals. 


\subsection{Risk Ranking}

It is a valuable procedure for prioritizing the recommendations resulted by HAZOP, and it is attained by the evaluation of the severity $(\mathrm{S})$ and probability $(\mathrm{P})$ of hazardous event sequences, in order to produce risk-outcomes which are illustrated in a table (e.g., matrix), implementing in this way the DMRA (i.e., decision-matrix risk-assessment, or risk-matrix) technique as an efficient tool for risk-estimations [45].

As soon as the hazards have been defined, the issue of designating the ratings of severity (S) and probability $(\mathrm{P})$ must be arranged. It is essential to note that frequency estimations and consequence estimations are successfully determined by experienced risk-managers. Thus, the risk $(\mathrm{R})$ is produced by establishing the risk-matrix according to relation of R-S x P [46].

In the recent work of Marhavilas et al. (2019) [2], the reader could find: (i) the necessary risk-ranking produced by the combination of the severity/reasons-frequency grades, according to the guidelines of IEC (2003) [47], and (ii) the resulted risk-matrix, according to Alaei (2014) [13].

\subsection{The Typical- and Fuzzy-Analytical-Hierarchy-Process}

During the past, there are many studies that use multi-criteria decision-making methods in cooperation with risk management methods, widely used in process industries. However, these studies used only Typical-AHP or Fuzzy-AHP, separately, and no comparative analysis was performed about the specific circumstances under which using fuzzy extensions of AHP could benefit the whole analysis.

More specifically, Abdelgawad and Fayek (2010) [48] used a Fuzzy-AHP approach to address the limitations of the traditional "failure mode and effect analysis" (FMEA) for managing risks in construction, and Zheng et al. (2012) [49] employed the Fuzzy-AHP method with trapezoidal fuzzy numbers for safety assessments in hot and humid environments.

Additionally, Basahel and Taylan (2016) [50] proposed a method for finding, assessing and evaluating safety risk factors at the construction sites (in Saudi Arabia), while Pour and Gheorghe (2017) [51] applied Fuzzy Risk Assessment (FRA) and AHP for determining and prioritizing the aggregate risk of oil and natural gas drilling process.

What is more, Gul (2018) [52] presented a significant review of OHS-risk assessment studies, via multi-criteria decision-making-based (MCDM) techniques. He incorporates in his work the fuzzy-side of MCDM techniques concerning OHS risk-assessment, and also refers to a structured methodology that uses prioritization (through T_AHP) in HAZOP analysis (presented by Othman et al. (2016) [14]).

In the article of Zhen et al. (2018) [53], a modified Fuzzy-AHP approach, used for importance degree of assessment of human, operational and organizational risk influencing factors at offshore maintenance work, and Fattahi and Khalilzadeh (2018) [54] developed an approach for evaluating risks in steel industry using FMEA, Fuzzy-AHP and also Fuzzy Multi-Objective-Optimization based on the Ratio-Analysis (MULTIMOORA) methods.

The Typical-AHP (T_AHP): The method defines the problem as a hierarchy and calculates the priorities (local and global) of the problem's factors (criteria and sub-criteria). The process' inputs are the decision-maker's judgments, namely the relative significance of each factor over another while performing pair-wise comparisons. The output result is a ranking of factors in descending order of their importance. The decision-maker must express the relative importance of the factors using a standard scale (Table 1) in order to transform the qualitative estimations of importance to numerical values.

One of the most important advantages of the T_AHP method is the integrated calculations for the decision-maker's consistency of judgments. Thus, the index CR (Consistency Ratio) is evaluated in order to check that the expert has a stable axiom system and is not assigning priorities "randomly". A pair-wise comparison matrix is characterized as consistent if the corresponding CR index is less than $10 \%$. This characteristic improves the reliability of the results. 
Table 1. The scale used to transform qualitative estimations to numerical values according to Saaty (1990) [8].

\begin{tabular}{cc}
\hline $\begin{array}{c}\text { Linguistic Variable } \\
\text { (Expressing the Significance of Factor I over Factor J to the Objective) }\end{array}$ & Value \\
\hline "Equal" & 1 \\
"Equal to Moderate" & 2 \\
"Moderate" & 3 \\
"Moderate to Strong" & 4 \\
"Strong" & 5 \\
"Strong to Very Strong" & 6 \\
"Very Strong" & 7 \\
"Very Strong to Extremely" & 8 \\
\hline
\end{tabular}

The Fuzzy AHP (F_AHP): Besides the proven efficiency of the Typical-AHP (T_AHP), it was criticized for not taking into consideration that there is uncertainty to the decision-maker's judgments. For this reason, the Fuzzy Extended AHP proposed by Chang (1996) [55] using Extent Analysis Method was combined with Triangular Fuzzy Numbers (TFNs) to better correspond the expert's choices. The fuzzy extended AHP is a very popular AHP alternative because of its simplicity and its proven efficiency. In our approach, the decision-maker's judgments are inserted and assigned to numerical values using a scale, proposed by Lamata (2004) [56], and are illustrated in Table 2. Note that each linguistic variable corresponds to a value of the standard Saaty's scale and then to a Triangular Fuzzy Number (TFN).

Table 2. Linguistic variables to Saaty's scale and Triangular Fuzzy Numbers (TFNs) according to Lamata (2004) [56].

\begin{tabular}{ccc}
\hline $\begin{array}{c}\text { Linguistic Variable } \\
\text { (Expressing the Significance of Factor I } \\
\text { over Factor J to the Objective) }\end{array}$ & Saaty's Scale & Triangular Number \\
\hline "Equal" & 1 & {$[1,1,1]$} \\
"Equal to Moderate" & 2 & {$[1,2,3]$} \\
"Moderate" & 3 & {$[2,3,4]$} \\
"Moderate to Strong" & 4 & {$[3,4,5]$} \\
"Strong" & 5 & {$[4,5,6]$} \\
"Vtrong to Very Strong" & 6 & {$[5,6,7]$} \\
"Very Strong" & 7 & {$[6,7,8]$} \\
"Extremely" & 8 & {$[7,8,9]$} \\
\hline
\end{tabular}

A Triangular Fuzzy Number $T=(t 1, t 2, t 3)$ has as membership-function the one of $\mu_{M}(x)$ defined by Zimmermann (2001) [57].

$$
\mu_{m}(x)=\left\{\begin{array}{ll}
0, & x \leq t 1 \\
\frac{x-t 1}{t 2-11}, & t 1 \leq x \leq t 2 \\
\frac{t 3-x}{t 3-t 2}, & t 2 \leq x \leq t 3 \\
0, & x \geq t 3
\end{array}\right\}
$$

Two TFNs $T_{1}=\left(t 1_{1}, t 2_{1}, t 3_{1}\right)$ and $T_{2}=\left(t 1_{2}, t 2_{2}, t 3_{2}\right)$ can be summed, subtracted, and multiplied with the operational laws described by Chang (1996) [55]. According to the process of the FEAHP, for 
a set of objects $O=\left\{o_{1}, o_{2}, \ldots, o_{n}\right\}$, and a goal set $G S=\left\{g_{1}, g_{2}, \ldots, g_{n}\right\}$, the extent analysis is applied resulting to $m$ values for each object:

$$
T_{g_{i}}^{1}, T_{g_{i}}^{2}, \ldots, T_{g_{i}}^{m} i=1,2, \ldots, n
$$

where all $T_{g_{i}{ }^{\prime}}^{j}(j=1,2, \ldots, m)$ are TFNs. The value of the fuzzy synthetic-extent, for each $i_{t h}$ object, is described by:

$$
F S E_{i}=\sum_{j=1}^{m} T_{g_{i}}^{j} \otimes\left[\sum_{i=1}^{n} \sum_{j=1}^{m} T_{g_{i}}^{j}\right]^{-1}
$$

These fuzzy numbers' output is transformed to crisp numbers using a defuzzification process. In the present study, we perform an average value approach, according to the work of Zimmermann (2001) [57], where a fuzzy number TFN $T=(t 1, t 2, t 3)$ is altered into a crisp number of CRN as:

$$
\operatorname{CRN}(M)=(l+m+u) / 3
$$

\section{Presentation of the SCOPI}

In this section, we give a technical illustration of a particular sour-crude-oil process industry (SCOPI), which has been chosen as a case study in this work, and additionally (a) constitutes the binder between the manuscript's sections concerning HAZOP, T_AHP and F_AHP techniques, and (b) could represent something in general, as far as the benefits of the application of the cooperative HAZOP_T AHP/F AHP framework on SCOPIs and other chemical industries, is concerned.

Depiction of the plant: A SCOPI performs a series of chemical and mechanical processes, which are applied on the sour-crude-oil (SCO), i.e., the one including hydrogen-sulfides and coming from the oil-production platform, in order to produce marketable crude-oil, incorporating the next units:

(i) The unit for the desalinization and stabilization of crude-oil: It desalinates and stabilizes approximately of $100 \mathrm{~m}^{3} / \mathrm{hr}$ crude-oil, coming from the platform, while the produced sour-gas is of $\sim 70,000 \mathrm{~m}^{3} /$ day.

(ii) The unit of the gas-compression, essential for compressing the sour-gas from stabilizer, and merging this with the stream of sour gas coming from the platform after it passes through a vessel, called three-phase separator that separates the well-fluids into: (a) gas and (b) two liquid kinds (oil and water). The cooling process of the two streams is realized by heat-exchanger units used to cool and/or condensate process streams with ambient air as the cooling medium rather than water, while later through a three-phase separator, there is a separation of the water and the "NGL".

(iii) The unit for "NGL"-stripping, wherein the produced "NGL" is stripped of several volatile hydrocarbons and hydrogen-sulfide $\left(\mathrm{H}_{2} \mathrm{~S}\right)$, before its mixture with the stabilized crude-oil.

Moreover, there is a variety of processes which happen, like the subsequent:

(i) The steam of 20.7 bar is directed to heat-exchangers in order to provide the essential energy for the "NGL"-stripping and also the crude stabilization

(ii) The water is mixed with the SCO to improve the desalinization process

(iii) The compressed dehydrated air to supply control air-actuated valves' functioning

(iv) The inaction of vessels or pipelines is achieved by occasional use of Nitrogen

The input-stream of the SCO arriving at the plant (through an $8^{\prime \prime}$ pipe), has a pressure of $\sim 20$ bars, a temperature equal to the sea's one (i.e., presents a seasonal fluctuation from $14{ }^{\circ} \mathrm{C}$ (winter) to $25^{\circ} \mathrm{C}$ (summer)), and constitutes a mixture that contains: (a) saturated volatile hydrocarbons, (b) a variety of volatile compounds (e.g., Hydrogen-Sulfide/ Nitrogen/Carbon-dioxide), (c) heavier compounds and (d) 
medium volatility hydrocarbons. The unprocessed SCO that inserts in the unit also includes dissolved sodium, salt-water, magnesium-chlorides, and calcium in tiny amounts of water. The salt-water is scattered in the crude-oil in the form of little balanced droplets, and due to their diameter, the droplets could be divided by an electrical field or by gravity in calm conditions. A characteristic laboratory analysis of the inward SCO is illustrated in Table 3.

Table 3. The input-composition of Sour-Crude-oil (SCO).

\begin{tabular}{|c|c|c|c|c|c|c|c|c|c|c|c|c|}
\hline \multicolumn{13}{|c|}{ Volatile-Low Molecular Weight } \\
\hline Component & $\mathrm{N}_{2}$ & $\mathrm{H}_{2} \mathrm{~S}$ & $\mathrm{CO}_{2}$ & $\cos$ & $\mathrm{CH}_{3} \mathrm{SH}$ & $\mathrm{C}_{2} \mathrm{H}_{5} \mathrm{SH}$ & $\mathrm{CS}_{2}$ & $\mathrm{C}_{1}$ & $\mathrm{C}_{2}$ & $\mathrm{C}_{3}$ & $\mathrm{iC}_{4}$ & $\mathrm{nC}_{4}$ \\
\hline MOLE \% & 0.01 & 21.89 & 0.68 & 0.01 & 0.03 & 0.01 & 0.04 & 0.65 & 1.06 & 2.99 & 1.24 & 3.32 \\
\hline \multicolumn{13}{|c|}{ Medium Volatile-Medium Molecular Weight } \\
\hline Component & $\mathrm{iC}_{5}$ & $\mathrm{nC}_{5}$ & $\mathrm{C}_{6}$ & $\mathrm{C}_{7}$ & $\mathrm{C}_{8}$ & $\mathrm{C}_{9}$ & & & & & & \\
\hline MOLE \% & 2.88 & 2.64 & 4.75 & 3.73 & 3.52 & 3.41 & & & & & & \\
\hline \multicolumn{13}{|c|}{ Heavy Components } \\
\hline Component & \multicolumn{2}{|c|}{$150-200^{\circ} \mathrm{C}$} & \multicolumn{2}{|c|}{$200-350{ }^{\circ} \mathrm{C}$} & \multicolumn{2}{|c|}{$\begin{array}{l}\text { Boiling Point }>350 \\
{ }^{\circ} \mathrm{C}\end{array}$} & & & & & & \\
\hline MOLE \% & \multicolumn{2}{|c|}{5.17} & \multicolumn{2}{|c|}{7.35} & \multicolumn{2}{|c|}{34.61} & & & & & & \\
\hline
\end{tabular}

The intention of the establishment: The unit has been designed to: (i) take away (from the SCO), water, hydrogen-sulfide, suspended particles, salts and a great amount of the volatile hydrocarbons, and (ii) transform SCO into stabilized crude-oil, which is proper and safer for the storage/transportation and additional treating in a refinery plant, and on the other side, has specific features as follows: (a) Vapor pressure-reid less than $12 \mathrm{PSI}$, (b) $\mathrm{H}_{2} \mathrm{~S}$ content less than $15 \mathrm{ppm}$, (c) water content around zero, as it is possible, and (d) salt content less than $28 \mathrm{mg} / \mathrm{lt}$. The subtraction of the dissolved hydrogen-sulfide gas is compulsory, due to its volatile, toxic and flammable features that could make transportation and storage considerably more unsafe. The existence of salts in the final product is dangerous because it can enhance the corrosion in the involved transportation pipelines and in the storage equipment. What is more, there are chloride salts, for instance magnesium-chlorides, which form the enormously corrosive hydrochloric-acid. Furthermore, the avoidance of the problematical function in the sour-gas handling unit is achieved by the separation of the produced sour-gas from its liquefiable contents, while the recovered "NGL" ought to be splitted from the containing $\mathrm{H}_{2} \mathrm{~S}$, due to the fact of a hazardous-spiking occurring in the crude-oil.

Likewise, stabilizers decrease the stored crude-oil volatility aiming that the final product has specific features as follows: (a) Vapor pressure-reid less than 12 PSI, (b) $\mathrm{H}_{2} \mathrm{~S}$ content less than $15 \mathrm{ppm}$, (c) water content around zero, as it is possible, and (d) salt content less than $28 \mathrm{mg}$ per $\mathrm{L}$. The subtraction of the dissolved $\mathrm{H}_{2} \mathrm{~S}$ gas is compulsory, due to its volatile, toxic and flammable features that could make transportation and storage considerably more unsafe. The presence of salts in the final product is dangerous because it can enhance corrosion in the involved steel pipelines for transfer or transportation and in the storage tanks and vessels. What is more, there are chloride salts, for instance magnesium-chlorides, which form an acidic environmental damage-mechanism, the Hydrochloric (HCL) Acid Corrosion.

Furthermore, the avoidance of the problematical function in the sour-gas handling-unit is achieved by the separation of the produced sour-gas from its liquefiable contents, while the recovered "NGL" ought to be splitted from the containing $\mathrm{H}_{2} \mathrm{~S}$, due to the fact of a hazardous-spiking occurring in the crude-oil.

The equipment of the establishment: In Table 4 we present synoptically the installation's equipment that is structured with heat-exchangers, compressors, vessels, pumps and control/relief valves, while an analytical description of their functioning, with extensive details and further information, is presented in the thesis of Filippidis (2017) [58] and the article of Marhavilas et al. (2019) [2]. Moreover, in Figure 1 we illustrate the process flow diagram (PFD) 
concerning the SCOPI's functioning, which is located in the north part of Greece. Besides, the PFD drawing depicts by dashed-line frames, the necessary HAZOP nodes (i.e., simpler parts) in order to perform, in the consequent sections, the HAZOP analysis.

Table 4. A synoptic presentation of the equipment of SCOPI.

\begin{tabular}{|c|c|c|}
\hline $\mathrm{Nr}$ & Parts of the Equipment & Basic Technical Clarifications \\
\hline \multirow{8}{*}{1} & \multirow{8}{*}{ Vessels } & $\begin{array}{l}\text { V-101: A three-phase separator vessel that releases sour-gas is from the } \\
\text { sour-crude-oil }\end{array}$ \\
\hline & & $\begin{array}{l}\text { ME-101: A desalinization vessel that separates the salts from the } \\
\text { sour-crude-oil }\end{array}$ \\
\hline & & V-102: A crude stabilizer column \\
\hline & & $\begin{array}{l}\text { V-103: A scrubber vessel that retains water which is contained in the gas } \\
\text { output from the top of V-102 }\end{array}$ \\
\hline & & $\begin{array}{l}\text { V-106: A vessel that acts as a buffer between the potable water intake and the } \\
\text { crude-oil pipeline injection point. }\end{array}$ \\
\hline & & $\begin{array}{l}\text { V-107: A "N G L" (Natural Gas Liquids) separator which collects the "N G L" } \\
\text { from the cooled gas stream from E-104 }\end{array}$ \\
\hline & & V-108: A condensate stripper column \\
\hline & & V-110: A three-phase separator \\
\hline \multirow{7}{*}{2} & \multirow{7}{*}{ Heat-Exchangers } & $\begin{array}{l}\text { There are two cooling heat-exchangers using sea-water and one using fans. There are } \\
\text { also two heating heat-exchangers that use } 20.7 \text { bar steam as a source of energy. There } \\
\text { is also a heat recovery heat-exchanger. }\end{array}$ \\
\hline & & E-101: A heat-exchanger which uses steam to heat the sour-crude-oil in V-102 \\
\hline & & $\begin{array}{l}\text { E-102: A heat-recovery heat-exchanger that utilizes the energy from the } \\
\text { stabilized crude-oil leaving V-102 to heat the incoming sour-crude-oil } \\
\text { entering the unit }\end{array}$ \\
\hline & & E-103: A cooling heat-exchanger that uses sea-water to achieve its purpose \\
\hline & & $\begin{array}{l}\text { E-104: An air-cooled heat-exchanger that is used to cool the stream of } \\
\text { sour-gas originating from C-101 and V-101 }\end{array}$ \\
\hline & & E-105: A heat-exchanger that uses steam to heat the sour-crude-oil in V-108 \\
\hline & & E-106: A water cooled heat-exchanger using sea-water as a cooling medium \\
\hline \multirow{3}{*}{3} & \multirow{3}{*}{ Pumps } & $\begin{array}{l}\text { P-101: A centrifugal pump to move the stabilized crude-oil from the bottom } \\
\text { of V-102 through E-102 and E- } 103 \text { to storage }\end{array}$ \\
\hline & & $\begin{array}{l}\text { P-102: A reciprocating pump to inject potable water in the } \\
\text { sour-crude-oil stream }\end{array}$ \\
\hline & & $\begin{array}{l}\text { P-103: A centrifugal pump to move the sour "N G L" from the bottom of } \\
\qquad \text { V-107 to V-108 for stripping }\end{array}$ \\
\hline 4 & Compressors & C-101: A two-stage double action reciprocating gas compressor \\
\hline \multirow{4}{*}{5} & \multirow{4}{*}{ Control-Valves } & $\begin{array}{l}\text { There are three types of control valves, i.e., pressure, flow and level valves that control } \\
\text { the respective element. They are pneumatic valves that draw their power from } \\
\text { compressed air supplied from a utilities unit. If the air supply is lost, for whatever } \\
\text { reason, the control valves will assume a predetermined position, either closed or open, } \\
\text { to ensure the safety of the installation. }\end{array}$ \\
\hline & & $\begin{array}{c}\text { Pressure Control Valves: PV-101, PV-102A, PV-102B, PV-103A, PV-103B, } \\
\text { PV-113, PV-117, PV-118 }\end{array}$ \\
\hline & & Flow Control Valves: FV-107, FV-110, FV-124, FV-127 \\
\hline & & $\begin{array}{l}\text { Level Control Valves: LV-101, LV-102, LV-104, LV-106, LV-109, LV-114, } \\
\text { LV-120, LV-121 }\end{array}$ \\
\hline \multirow[b]{2}{*}{6} & \multirow[b]{2}{*}{ Relief-Valves } & $\begin{array}{l}\text { There are several pressure relief-valves and alarm-switches to ensure the safe } \\
\text { operation of the facility. }\end{array}$ \\
\hline & & $\begin{array}{c}\text { PSV103-104, PSV105-106, PSV107, PSV108-109, PSV110-111, PSV115-118, } \\
\text { PSV116-117, PSV121-123, PSV126-133, PSV127-128, PSV129-132, } \\
\text { PSV134-135, PSV138, PSV139, PSV140, PSV141 }\end{array}$ \\
\hline
\end{tabular}




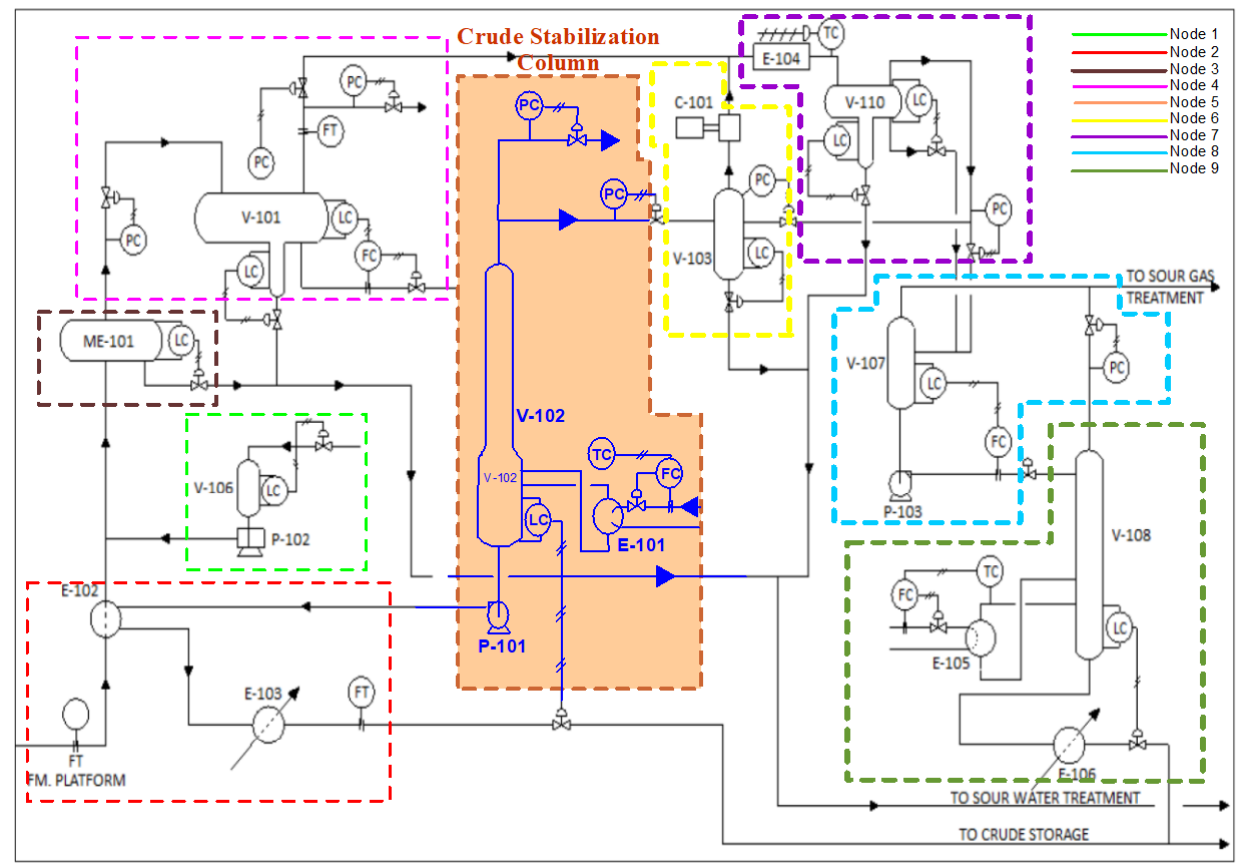

Figure 1. The Unit Process Flow Diagram (PFD) concerning the SCOPI's functioning.

\section{Case Study: Application on a SCOPI Plant}

\subsection{The Procedural Framework of HAZOP_TAHP/FAHP}

In Figure 2, we illustrate the flowchart of a RAA process (as a part of the risk management) after the incorporation of a HAZOP_TAHP/FAHP framework and the DMRA risk-ranking tool.

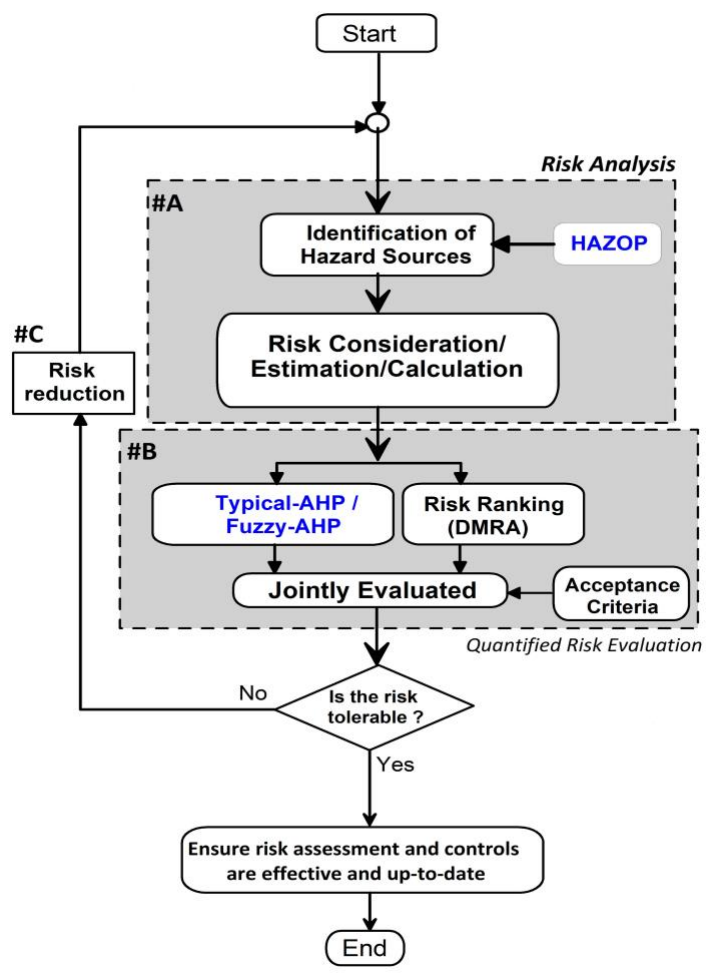

Figure 2. The flow diagram of a RAA process (as a part of the risk management) after the incorporation of a HAZOP_TAHP/FAHP framework. 
This methodological framework is composed of three (3) separate sub-phases: the risk-analysis $(\# \mathrm{~A})$ and risk-evaluation (\#B), constituting the risk-assessment stage, and also the risk reduction/control $(\# C)$. In particular, the first sub-process, which includes the identification of hazard sources and the risk-consideration, incorporates HAZOP analysis, while the second sub-process considers the combination and joint-evaluation of Typical-AHP/Fuzzy-AHP and also DMRA, as a portion of QRE (i.e., quantitative risk-evaluation). The T_AHP/F_AHP process is applied for prioritizing the risk-factors of the project. Eventually, the third module \#C incorporates safety-related decision-making. Besides, it is worthwhile mentioning, that the creation of this drawing was based on the safety-topics/guidelines of the works by Høj and Kröger (2002), Marhavilas (2015) and ISO/IEC (1999, 2009) [45,59-61].

\subsection{Application of the HAZOP Process}

The systematic HAZOP study was executed in a SCOPI, which is placed in NE-Greece, by the members of the HAZOP team which consisted of two unit-operators, e.g., the plant-operation administrator and the maintenance-department manager. The installation-operation superintendent is a capable chemical engineer with substantial capability in CPIs, whereas the maintenance-department superintendent is a mechanical engineer. The plant-operators have a significant ability for operating the SCOPI's units, and important experience on preceding incidents. The HAZOP sessions were accomplished through a six-month period, including entirely twelve sessions. The first two sessions included the explanation of the SCOPI process to the team, and also the selection of the HAZOP-nodes. Below, it is collocated the essential steps for implementing the HAZOP process, as follows:

(1) Selection of the nodes and intentions: Taking into consideration the equipment's operation and their interconnectivity, wholly nine nodes were chosen, such as:

(i) "Node-1", which is the "Water-injection system"

(ii) "Node-2", which is the "Reheating/cooling exchangers"

(iii) "Node-3", that means, the "Desalting process unit"

(iv) "Node-4", i.e., the "Low-Pressure L.P. separator"

(v) "Node-5", which is the "Crude stabilizer column"

(vi) "Node-6", that means the "Gas compressor"

(vii) "Node-7", e.g., the "Compressor gas cooling and liquids recovery"

(viii) “Node-8", i.e., the "Condensate stripper column" that feeds vessel and "Pump P103"

(ix) "Node-9", the "Condensate s t r i p p e r and cooling unit"

(2) Guideword and safe limits of the process: The central idea of HAZOP method is the identification: (a) of deviations (i.e., hazards) from the normal and prospective (by the design) safe-state, and also (ii) the crucial process parameters, like: "Composition", "Flow", "Level", "Phase", "Pressure" and "Temperature". Moreover, the proper guidewords concerning the deviation from the safe operation are: "Less", "More", "No", "Other than" and "Reverse", which are combined with the previous referred process factors (parameters) in order to define the deviation from the conditions of a safe situation.

(3) The identification of the causes and the hazards: This step is realized after the previously referred two steps, whence the HAZOP team identifies the root causes for any hazard that is associated with a particular node.

(4) The determination of consequences: At this step, the members of the HAZOP team define the consequences of any hazard in association with safety, environmental, and economical aspects.

(5) The identification of safeguards: At this step, the HAZOP team documents, in a HAZOPworksheet, the related safeguards in order to recognize the hazards and prevent the consequences.

(6) Recommendations: At this step, the necessary recommendations about decreasing the risk-level are discussed and analyzed by HAZOP's team members and are recorded in the worksheet of HAZOP. 
It is worthwhile to mention, that the risk-matrix used in RAA, will have the structure presented by Table 4, involved in the paper of Marhavilas et al. (2019) [2]. Thus, (i) the probability of the recognized hazards and (ii) the failure-rate of ordinary control-equipment (like level/pressure-transmitters), were specified by the usage of an information-base of preceding incidents in SCOPI-units with equivalent equipment. On the other side, the evaluation of the hazards severity was performed with the accordance of the team's members and their individual decision. Besides, Table 5 illustrates the "Guidewords" and "Elements", which were used to generate the deviations produced by the HAZOP procedure.

Table 5. Depiction of "Guidewords" and "Elements" of the HAZOP study.

\begin{tabular}{|c|c|c|c|c|c|c|}
\hline \multicolumn{7}{|c|}{ Elements } \\
\hline Level & Flow & Pressure & Temperature & Composition & Phase & Containment \\
\hline \multicolumn{7}{|c|}{ Guidewords } \\
\hline More & & Less & & & & Other than \\
\hline
\end{tabular}

At the beginning of the study, we depicted by drawing colored dashed-line frames, the existence of the previously referred nine nodes, as structural parts of the unit's 'process-flow-diagram' (PFD) presented in Figure 1.

The first node (Node-1) which is the water-injection system, was analyzed (by HAZOP) in association with the general process parameters (or elements) of "Level", "Pressure", "Flow" and "Containment".

Node-2, i.e., the preheating and cooling exchangers, was analyzed taking into account the elements "Flow", "Pressure", "Temperature", "Composition" and "Containment".

The HAZOP analysis of the installation's desalting vessel (i.e., Node-3) was achieved by using the elements "Level", "Flow", "Pressure", "Temperature", "Composition" and "Containment".

Besides, the HAZOP analysis of the low-pressure separator vessel (of Node-4) was conducted in association with the process parameters: "Level", "Flow", "Pressure", "Phase" and "Containment".

Node-5, which is the crude stabilization column-group of equipment, was HAZOP-analyzed taking into consideration the elements of "Composition", "Containment", "Flow", "Level", "Pressure" and "Temperature".

What is more, Node-6 (i.e., the 'gas compressor station' and its supplementary scrubber vessel) was analyzed taking into account the elements of "Containment", "Flow", "Level", "Phase", "Pressure", and "Temperature".

In addition, the HAZOP analysis of the compressor gas cooling and liquid-recovery system (in Node-7), was performed by the elements "Containment", "Flow", "Level", "Pressure" and "Temperature".

Moreover, Node-8, i.e., the condensate stripper column that feeds vessel V-107 and pump P103, was HAZOP-analyzed in association with the elements of "Containment", "Flow", "Level", and "Pressure".

Finally, the HAZOP analysis in Node-9, which is the condensate stripper and cooling system of the facility, was applied by the elements "Containment", "Flow", "Level", "Pressure" and "Temperature".

Taking into consideration the sizable SCOPI's plant, the large number of the HAZOP-nodes, and their operability as well, we concentrated, via this article, on a considerable node of the SCOPI's plant, as far as the risk is concerned. More explicitly, we selected Node-5, for applying (as an instance) the conventional HAZOP-DMRA technique, in order to identify the likely fault causes due to irregular deviations. Hence, for this node, which is shown in Figure 3, we operate and implement HAZOP analysis using the elements "Level", "Flow", "Pressure", "Temperature", "Composition" and "Containment" having as final outcomes the ones shown in Tables A1-A6, correspondingly. We elucidate, that the conventional HAZOP/DMRA technique was also performed for the rest nodes in order to achieve the full application of the HAZOP-DMRA scheme in the specific SCOPI. 


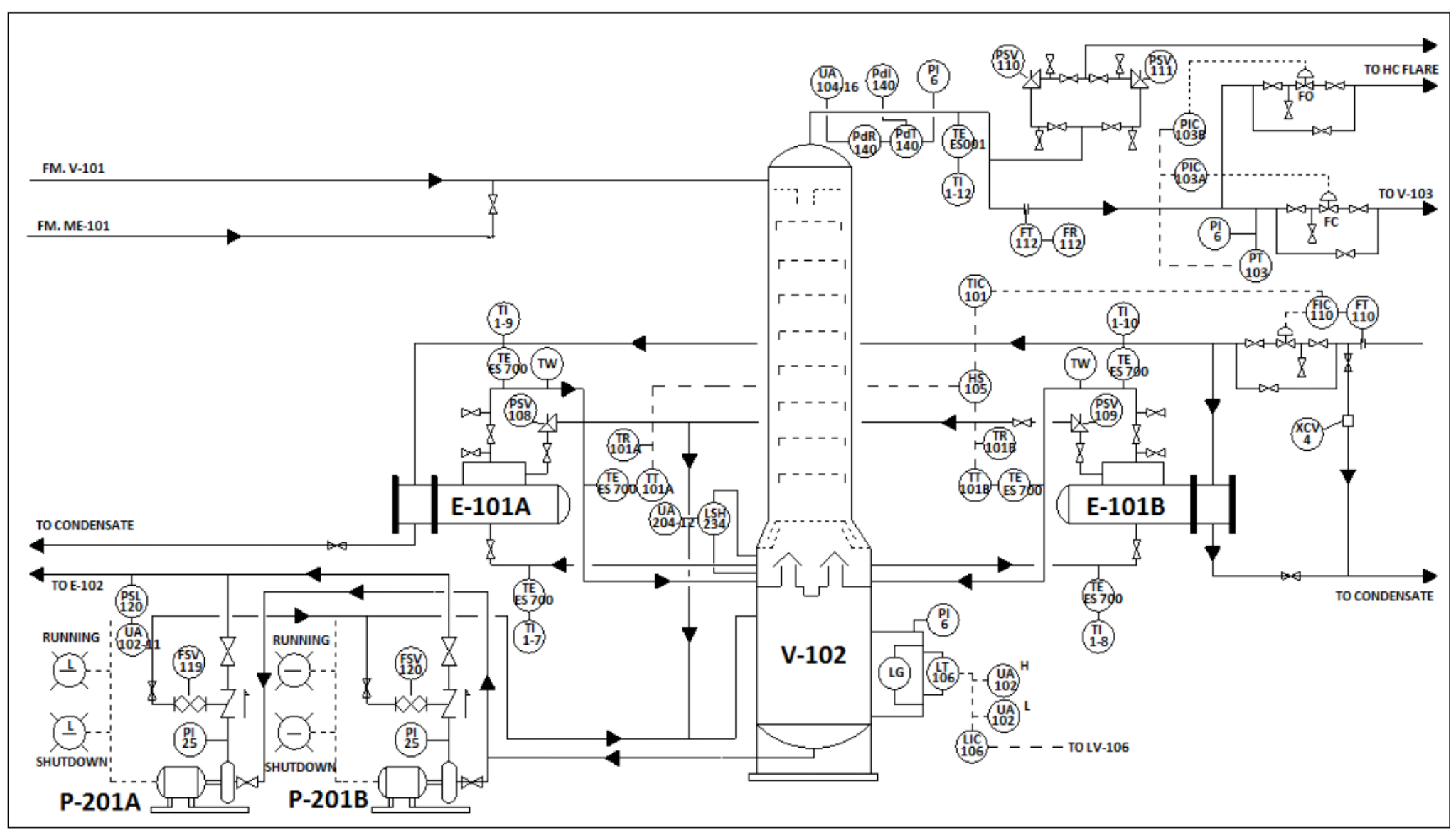

Figure 3. The crude stabilization column of "Node-5". 
In the tables originated from the HAZOP study, all the plausible sources and hazards due to a particular deviation have been defined, and with the intention that HAZOP study forms a useful guide for providing a list of priorities to the maintenance/inspection staff. Many of them are ordinary for multiple deviations and some additional analysis was essential to determine distinctive hazards, which have been categorized into the next three classes: The first one corresponds to 'hazards to human life and the environment' and has been analyzed thoroughly in the work of Marhavilas et al. (2019) [2]. The second one, presents the 'operability hazards' i.e., the ones associated with the product quality and economic operation of the establishment and will be analyzed comprehensively in a forthcoming work. Finally, the third category includes the 'hazards with both economic and health (or environmental) impact', which means the hazards that influence the economical performance of the establishment and concurrently cause a risk to human life and/or to the environment, and they are depicted in Table 6.

Table 6. Deviations (or hazards) that include "economic and health and/or environmental" impacts.

\begin{tabular}{|c|c|}
\hline $\mathrm{Nr}$ & Deviations/Hazards \\
\hline “1” & Higher temperature crude to tanks due to more oil flow \\
\hline “2” & Stabilized crude-oil containing $\mathrm{H}_{2} \mathrm{~S}$ due to leak in E-102 \\
\hline “ $3 "$ & No crude stabilization due to column flooding \\
\hline “4” & Volatile hydrocarbons to crude storage tanks from V-102 \\
\hline “5” & Stabilized crude containing $\mathrm{H}_{2} \mathrm{~S}$ due gas from $\mathrm{V}-102$ \\
\hline “6” & C-101 damage due to overheating \\
\hline “7" & Hydrate formation in $\mathrm{V}-110$ \\
\hline “8” & "NGL" release in the sea \\
\hline
\end{tabular}

Several serious deviations (given by Table 6) are the ' $\mathbf{H}_{2} \mathbf{S}$ releasing' and also the 'hydrocarbons releasing', taking into consideration the impacts of bad-breathing that might have happened to people, producing substantial problems concerning health. What is more, when hydrocarbons are taken into consideration, these would be liquid and/or gas. The discrimination can be hard due to the volatility of these components. In addition, "NGL" can be in liquid form, inside a vessel under pressure, and be evaporated nearly immediately, when it is exposed to atmospheric conditions. An additional important aspect, which has financial effects on the plant's operations, is the crude-oil storage, when this specific kind of crude-oil does have proper quality specifications (for instance, due to enhanced $\mathbf{H}_{\mathbf{2}} \mathbf{S}$ content, and/or because of the existence of water/salt content).

\subsection{Application of the Typical-AHP and Fuzzy-AHP Processes}

In light of the outcomes of the prior HAZOP/DMRA scheme (shown by Table 6), we continue to the subsequent stage, e.g., the execution of the Typical-AHP and Fuzzy-AHP processes, on the SCOPI's plant (as a case study), by the usage of the hazards depicted in Table 6, so as to entirely implement the HAZOP_TAHP/FAHP approach.

The problem of assessing eight hazard factors with health and environmental impacts in a SCOPI is modeled by a hierarchy in which the goal is safety's prevention while the first level consists of eight hazard factors (Figure 4).

It is worthwhile to mention that, the decision-maker fills the pair-wise comparison matrix presented in Table 7 with numbers that correspond to his preferences about the risks' relative importance, as described by linguistic variables (Tables 1 and 2). Firstly, the Typical-AHP is applied to calculate each hazard's weight and construct the ranking. An important element of the Typical-AHP calculation is the consistency-ratio (CR) estimation, which, in a case that is below $10 \%$ means that the judgments of the expert are consistent and the ranking is reliable. Note that, in the present case the consistency-ratio is found to be $C R \leq 10 \%$. 


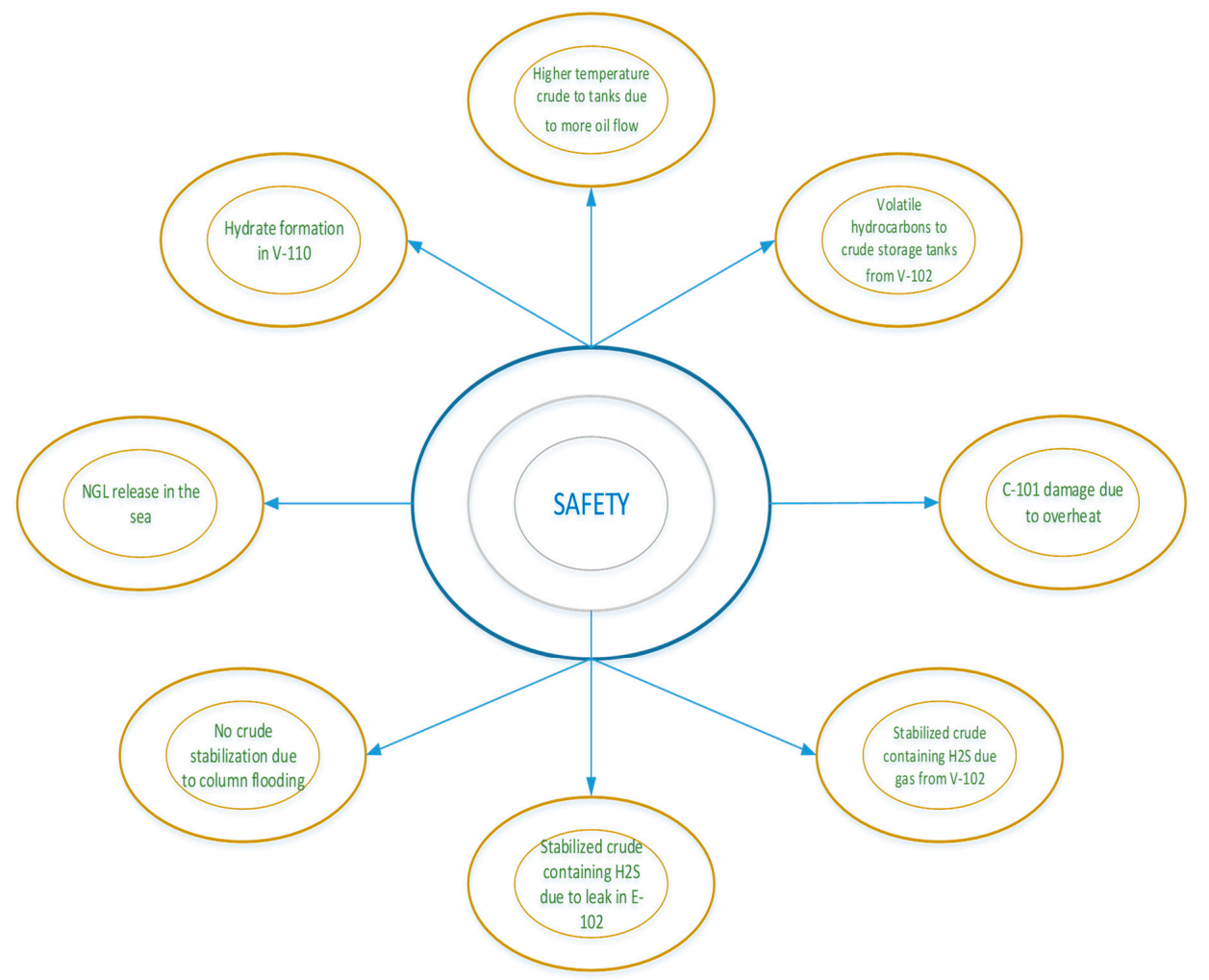

Figure 4. The hierarchy.

Table 7. The expert's judgments serving as input on both Typical-AHP and Fuzzy-AHP.

\begin{tabular}{ccccccccc}
\hline Safety & [01] & [02] & [03] & [04] & [05] & [06] & [07] & [08] \\
\hline$[01]$ & 1.00 & 3.00 & 2.00 & 3.00 & 6.00 & 0.50 & 3.00 & 0.50 \\
{$[02]$} & & 1.00 & 0.33 & 0.20 & 2.00 & 0.17 & 0.50 & 0.25 \\
{$[03]$} & & & 1.00 & 0.33 & 3.00 & 0.20 & 0.50 & 0.25 \\
{$[04]$} & & & & 1.00 & 5.00 & 0.50 & 2.00 & 0.33 \\
{$[05]$} & & & & & 1.00 & 0.14 & 0.25 & 0.13 \\
{$[06]$} & & & & & & 1.00 & 4.00 & 0.33 \\
{$[07]$} & & & & & & & 1.00 & 0.50 \\
{$[08]$} & & & & & & & & 1.00 \\
\hline
\end{tabular}

The weights for each hazard calculated by Typical-AHP and F_AHP, are illustrated in Table 8 and also the rankings of hazards extracted by each method, in descending order of importance. It is worth mentioning that both methods use as input the same judgments pair-wise comparison matrix.

Table 8. Weights and rankings derived with both Typical- and Fuzzy-AHP.

\begin{tabular}{|c|c|c|c|c|c|c|c|}
\hline \multicolumn{2}{|c|}{$\begin{array}{l}\text { Weights for the Hazards } \\
\text { (Typical-AHP) }\end{array}$} & \multicolumn{2}{|c|}{$\begin{array}{l}\text { Final Ranking } \\
\text { (Typical-AHP) }\end{array}$} & \multicolumn{2}{|c|}{$\begin{array}{l}\text { Weights for the Hazards } \\
\text { (F_AHP) }\end{array}$} & \multicolumn{2}{|c|}{ Final Ranking (F_AHP) } \\
\hline [01] & $16.50 \%$ & {$[08]$} & $28.17 \%$ & [01] & $18.00 \%$ & {$[08]$} & $25.29 \%$ \\
\hline$[02]$ & $3.92 \%$ & [06] & $22.53 \%$ & [02] & $4.70 \%$ & [06] & $25.11 \%$ \\
\hline [03] & $6.19 \%$ & {$[01]$} & $16.50 \%$ & [03] & $8.51 \%$ & [01] & $18.00 \%$ \\
\hline [04] & $12.22 \%$ & [04] & $12.22 \%$ & [04] & $16.14 \%$ & [04] & $16.14 \%$ \\
\hline$[05]$ & $2.38 \%$ & [07] & $8.08 \%$ & {$[05]$} & $2.66 \%$ & [07] & $10.26 \%$ \\
\hline$[06]$ & $22.53 \%$ & [03] & $6.19 \%$ & [06] & $25.11 \%$ & [03] & $8.51 \%$ \\
\hline [07] & $8.08 \%$ & {$[02]$} & $3.92 \%$ & [07] & $10.26 \%$ & [02] & $4.70 \%$ \\
\hline$[08]$ & $28.17 \%$ & [05] & $2.38 \%$ & [08] & $25.29 \%$ & [05] & $2.66 \%$ \\
\hline
\end{tabular}


According to the Typical-AHP calculations, the factors "NGL release in the sea" (08) and "C-101 damage due to overheating" (06) are more important since their weights are $28.17 \%$ and $22.53 \%$, respectively. The second more important group consists of the factor "Higher temperature crude to tanks due to more oil flow" (01) with weight of $16.5 \%$, and the (04) "Volatile hydrocarbons to crude storage tanks from V-102" with $12.22 \%$ score. The third more important group includes hazards with small differences on their weights but they are responsible for the 20.57\% (cumulatively) of the total risk. The risk factors belonging to this group are "Hydrate formation in V-110" (07), "No crude stabilization due to column flooding" (03), "Stabilized crude containing $\mathbf{H}_{\mathbf{2}} \mathbf{S}$ due to leak in E-102" (02), and "Stabilized crude containing $\mathbf{H}_{\mathbf{2}} \mathbf{S}$ due gas from V-102" (05).

The calculation with Fuzzy-AHP, results to a same ranking of the hazards, as shown in the last column of Table 8. However, the distance of the weights between the first factor [08] and the second factor [06] is dramatically reduced, meaning that the F_AHP can better describe the uncertainty of the expert's choices. Additionally, it is observed that except the ranked-as more important-hazards, the scores of all the other hazards are increased, and especially the financial impact hazards ([06], [01], [03]) are responsible (cumulatively) for the $51.62 \%$ of the total risk instead of the $45.22 \%$ found by T_AHP. In addition, the scores of the hazards with impact on the workers' health are higher than these computed by Typical-AHP, namely the factor [04] is weighted to $16.14 \%$ and [07] to $10.26 \%$. This finding is of great interest for business managers and safety executives who, usually, are concerned more about workers' safety and health issues, as well as, about business profits, rather than impacts on the environment. Additionally, the above findings could be used for prioritizing investments in health and safety prevention measurements.

These results verify the findings of the recent study of Chan et al. (2019) [62] wherein the circumstances under which the F_AHP is preferred over Typical-AHP are stated. More specifically, in our case, quantitative difference was observed while the pair-wise comparison matrix is highly consistent, and the importance of hazards is relatively close to one another. Due to the presence of the above conditions, the F_AHP is used, having as a result the efficiency's rising of the proposed approach, since the proven ability of Fuzzy-AHP to handle uncertainty is necessary for applications such as risk assessment in industry where ambiguous conclusions might affect health and safety of employees.

In the beginning of this article, the execution of the conventional HAZOP study is attained, to identify the potential consequences and causes which correspond to irregular conditions. Thus, several serious hazards/deviations (depicted in Table 6) are the following: "hydrocarbons releasing", " $\mathrm{H}_{2} \mathrm{~S}$ releasing", and "NGL releasing", with regards to affecting breathing that may happen to people, causing substantial problems to their health. In association with the results of the HAZOP technique, on the one hand, and also the utilization of the DMRA for risk-ranking, on the other side, the T_AHP and the F_AHP procedure is then applied consecutively, to expand HAZOP study by prioritizing the risks in the SCOPI's establishment. The choice of the explicit SCOPI for executing the HAZOP study is greatly valuable for the implementation of this approach, due to a variety of hazards included in the process, and because of its innovative design.

The hazards' recognition (by HAZOP study) denotes that we could systematically assess and judge the SCO process. This technique can be, consequently, considered as an efficient method, for hazards' identification and prediction, and it may enhance the safety levels, obstruct accidents and increase the reliability of systems, through the decrease of operational and environmental problems [13]. The specific SCOPI, under consideration in this article, was proved to be trustworthy and safe, at such a level that right establishment inspections and maintenance are imposed. The arranged approach and systematic analysis that HAZOP technique provides, is a brilliant tool for judging the SCOPI's parts' operation. In general, the equipment of chemical industries (and of SCOPIs as well) is extremely expensive, because of the unique technical and quality specifications, and due to the fact, that such equipment is regularly custom-engineered to particular applications. Therefore, any act of changing (entirely or partially) the equipment, creates significant economic consequences to the corporation. 
To be brief, the examined SCOPI's plant, despite its lengthy lifetime, presents tolerable risk in its functioning, because of the appropriate inspection and maintenance [2].

The main results derived by applying the T_AHP and F_AHP are the following: (i) The outcomes of the T_AHP and F_AHP process, agree (between them) on the final results as far as the hazards' ranking is concerned; (ii) The most important source of risk is the deviation $\mathrm{Nr}$ [08], which has an environmental impact. This finding is of great value given the fact, that both at the state/national level (with the development of a legislative framework for environmental impacts) and also at the international level (with global transnational agreements on the environmental impact of industrial activity), the international community is becoming more and more aware of environmental issues (e.g., $\mathrm{CO} 2$ footprint, climate change, industrial pollutants, etc.); (iii) F_AHP enhances (in comparison with T_AHP) the hazards' importance factors which have impacts on the financial consequences on the company (e.g., deviations [06], [01], [03], [02]), as well as the impact on employee health (e.g., deviations [04], [07]). This may be of greater interest to business manager and safety executives, who are firstly concerned with the safety/health of workers, and the economical factor of their business, and less with the impact on the environment.

In the present approach, we used F_AHP and T_AHP, so as to rank hazards, while exploiting the expertise of the decision-maker. The hazards' ranking using F_AHP remains the same with the ranking using T_AHP, but the scores for each hazard are quite different, and the relative distances between them are smaller/larger, respectively. These different scores are very important, in case of spending budget, to safety measures, as they can lead to over/under-investing in measures for a hazard, resulting to lower effectiveness in prevention of accidents. Additionally, as stated in Chan et al. (2019) [62], given that there are present "judgments with dominant preference and equal important elements" in our case, the total effectiveness of the approach could be benefited by using the Fuzzy-AHP.

\section{Discussion and Conclusions}

This work concentrates on the spreading out of the HAZOP process (i.e., one of the most frequently applied in industry) and more particularly, on the widespread presentation: (i) of the conventional HAZOP study, and (ii) of an extended HAZOP methodology with DMRA, combined with the Typical-Analytical-Hierarchy-Process (T_AHP) and also with the Fuzzy-Analytical-Hierarchy-Process (F_AHP). Additionally, the cooperative HAZOP_TAHP/FAHP scheme is performed as a unified approach to identify and prioritize crucial points and impending hazards in a SCOPI (i.e., a case study), which is remarkably important, since it combines many hazards, like gases, toxic gases and flammable liquids as well. Hence, this is the reason for choosing the SCO chemical process as a case study.

This article provides a framework for systematically evaluating economical, health and also environmental impacts, and prioritizing the risks by hazards or deviations from the normal operation of a specific chemical process (i.e., a SCOPI). In particular, an individual technique cannot attain optimal RAA results in the workplaces, and future points of view should focus on the concurrent application of diverse RAA methods. Consequently, the development of an integrated RAA technique, which will combine a well-considered selection of wide-ranging techniques (like HAZOP, DMRA, T_AHP, F_AHP, etc.) would make able industries achieve substantial results in risk assessment [20-22].

Besides, this study is an effort to downgrade the negative aspects of conventional HAZOP through the jointed HAZOP_TAHP/FAHP approach. In the literature, the improvement of HAZOP methodology is underway, so that various techniques have been incorporated in traditional HAZOP studies, like the subsequent combinations: (a) HAZO-DMRA that presented by Alaei et al. (2014) [13], (b) Fuzzy-DMRA by Gul and Guneri (2016) [63], (c) HAZOP-AHP by Othman et al. (2016) [14] and Marhavilas et al. (2019) [2], (d) HAZOP-dynamic FTA by Guo and Kang (2015) [64], (e) Fuzzy-based HAZOP by Ahn and Chang (2016) [65], (f) Fuzzy multi-attribute HAZOP by Cheraghi et al. (2019) [15], (g) HAZOP-Fuzzy TOPSIS by Cheraghi et al. (2019) [15], and (h) HAZOP-Fuzzy AHP by Marhavilas et al. (2020) [66].

It is worth mentioning that for the first time, through this work, we designate the weight of risk-factors and prioritize the hazards by using together T_AHP and F_AHP in the environment of 
HAZOP. Likewise, the usage of the HAZOP_TAHP/FAHP framework on a SCOPI shows that this combined technique displays a more distinct environment, as far as the hazards' ranking is concerned, compared to conventional HAZOP.

What is more, the Fuzzy-extended AHP was applied in the present study because of its usability, since only the expert has to fill in a pair-wise comparison matrix with relative importance of each hazard of the analysis over another. Next, the assignment of linguistic values (to Triangular Fuzzy Numbers) rises the efficiency of the analysis, as the uncertainty of the expert's judgments is taken into account, which leads to a more reliable ranking in applications such as health and safety hazards analysis, due to the impacts on the environment and workers.

It is noteworthy that by focusing on the deviations (illustrated in Table 6 and defined by HAZOP study) with economic/health/environmental impacts: (i) we broaden, through this article, the outcomes of our previous work, which have already integrated HAZOP with AHP [2], and (ii) we unveil the sustainable dimension of the HAZOP_TAHP/FAHP approach, having as the main gain, the improvement of the sustainable living in the specific SCOPI, taking into account that a significant part of literature [18] utilized the issue of sustainability as a frame for the development of OHS RAA techniques.

In fact, the idea of sustainability was used as a frame to develop OHS RAA methods, and the greater part of OHS subjects are associated with enterprises' compliance with legislation requests, while a considerable part of literature integrated OHS issues into the concept of social responsibility of organizations, which should go beyond the law by adopting voluntary OHS standards [18]. Furthermore, the implementation of the methodology that developed within this article could be useful to reorganize the production processes of some industries in order to reduce operational risk and to lead sustainable manufacturing. To this logic, the concept of sustainability is utilized as a frame for the development of OHS RAA techniques.

Therefore, this is the new contribution of this piece of writing (in comparison with previous work), and also one of its main aims. Likewise, an extra intention is to disclose that the proposed HAZOP_TAHP/FAHP framework could be a valuable means for decision-makers to meliorate OHS and process safety, as well, and to support the sustainable operation of this SCOPI.

We have the opinion that the usage of the new alternative framework, which is presented in this paper, would help industries in the achievement of occupational risk prevention. In future work, we are planning (a) the development of additional RAA frameworks (including more stochastic/deterministic techniques), and (b) the application on OHSS of SCOPIs and other industries. This means that according to Zheng and Liu (2009) [67], there is a potentiality for the combination of more different techniques (like neural networks, Markov chains, grey model, Bayesian networks, etc.) with traditional HAZOP.

In conclusion, the joint-analysis (by HAZOP_TAHP/FAHP) in this article can afford a reliable base to enhance process safety and meliorate OHS. Similarly, it might be a constructive means for the decision-makers to: (a) evaluate the urgent situation of investment's restricted resources in measures preventing particular deviations (like the ones with economic, health and environmental consequences), and (b) to endorse the sustainable growth of this industry. Besides, the novelty and key points of this study or, in other words, its contributions to "new knowledge" as far as health and safety science are concerned, could be focused on: (i) the development of an alternative beneficial RAA process (i.e., the HAZOP_TAHP/FAHP one), (ii) the improvement of RAA processes due to combination of separate RAA techniques with real data of deviations (hazards), (iii) the comparison of their outcome risk-estimation results (T_AHP vs. F_AHP), (iv) the application of this new technique (as a case study) on a SCOPI, which presents significant scientific interest, and (v) the enrichment of the scientific literature with new results for the OHSS and principally in the field of sour-crude-oil processes.

Author Contributions: Conceptualization, P.K.M., D.E.K.; data curation, P.K.M., M.F., G.K.K.; formal analysis, P.K.M., D.E.K.; investigation, P.K.M., G.K.K., D.E.K.; methodology, P.K.M., D.E.K.; writing—original draft, P.K.M., M.F., G.K.K.; writing-review and editing, P.K.M., M.F., G.K.K., D.E.K. All authors have read and agreed to the published version of the manuscript. 
Funding: This research received no external funding.

Conflicts of Interest: We declare no conflict of interest.

\section{Acronyms/Abbreviations}

\begin{tabular}{|c|c|}
\hline AHP & "Analytical Hierarchy-Process" \\
\hline BDV & "Blowdown Valve" \\
\hline CCPS & "Center for Chemical Process Safety" \\
\hline CIA & "Chemical Industries Association" \\
\hline CPI & "Chemical Process Industry" \\
\hline DMRA & “Decision-Matrix Risk-Assessment" \\
\hline EPSC & "European Process Safety Centre" \\
\hline ESD & "Emergency Shutdown" \\
\hline ESDV & "Emergency Shutdown Valve" \\
\hline F_AHP & "Fuzzy-Analytical-Hierarchy-Process" \\
\hline FEAHP & “Fuzzy Extended Analytical Hierarchy-Process" \\
\hline FEED & “Front-End Engineering Design" \\
\hline FMEA & "Failure Mode and Effect Analysis" \\
\hline FTA & "Fault Tree Analysis" \\
\hline HAZOP & "Hazard and Operability" \\
\hline ICI & "Imperial Chemical Industries" \\
\hline ICST\&D & "International Conference on Sustainable Technology and Development" \\
\hline IEC & "International Electrotechnical Commission" \\
\hline LAHH & “Level Alarm High High" \\
\hline LALL & "Level Alarm Low Low" \\
\hline LNG & "Liquefied Natural Gas" \\
\hline MCDM & "Multi-Criteria Decision-Making" \\
\hline NGL & "Natural Gas Liquids" \\
\hline OHSS & "Occupational Health and Safety System" \\
\hline P\&IDs & "Piping and Instrumentation Diagrams" \\
\hline PHA & "Preliminary-Hazard-Analysis" \\
\hline PFD & “Process Flow Diagrams" \\
\hline PIC & "Pressure-Indicator-Controller" \\
\hline PPE & "Personal-Protective-Equipment" \\
\hline PSV & "Pressure-Safety-Valve" \\
\hline PT & “Pressure-Transmitter" \\
\hline PV & "Pressure-Valve" \\
\hline QRE & “Quantified-Risk-Evaluation” \\
\hline QRA & “Quantitative Risk Assessment" \\
\hline RA & “Risk Assessment" \\
\hline RAA & "Risk Analysis and Assessment" \\
\hline SCO & “Sour-crude-oil" \\
\hline SCOPI & "Sour-crude-oil Process Industry" \\
\hline SIL & "Safety Integrity Level" \\
\hline SMS & “Safety Management System” \\
\hline STPA & "System Theoretical Process Analysis" \\
\hline T_AHP & "Typical-Analytical-Hierarchy-Process" \\
\hline TFN & “Triangular Fuzzy Number" \\
\hline
\end{tabular}

\section{Appendix A}

The appendix contains the tables which illustrate the outcomes from the implementation of HAZOP analysis using the elements "Level", "Flow", "Pressure", "Temperature", "Composition" and "Containment", concerning "Node-5". 
Table A1. The "Level"-Element of "Node-5".

\begin{tabular}{|c|c|c|c|c|c|c|c|c|}
\hline Node & 5 & & & & & & & \\
\hline Element & Level & & & & & & & \\
\hline \multirow{2}{*}{ Guideword } & \multirow{2}{*}{ Deviation } & \multirow{2}{*}{ Possible Cause } & \multirow{2}{*}{ Consequences } & \multirow{2}{*}{ Safeguards } & \multicolumn{3}{|c|}{ Risk Matrix } & \multirow{2}{*}{ Recommendations } \\
\hline & & & & & $\mathrm{s}$ & L & $\mathbf{R}$ & \\
\hline \multirow{3}{*}{ More } & \multirow{3}{*}{$\begin{array}{l}\text { Higher level in V-102 } \\
\text { bottom }\end{array}$} & $\begin{array}{c}\text { 1. P-101 } \\
\text { shutdown }\end{array}$ & \multirow{3}{*}{$\begin{array}{l}\text { No production } \\
\text { to storage } \\
\text { Column flooding, poor } \\
\mathrm{H}_{2} \mathrm{~S} \text { stripping }\end{array}$} & $\begin{array}{ll}\text { - } & \text { 1.1 High Level } \\
\text { Alarm LT-106 } \\
\text { - } & \text { 1.2 Spare P-101 } \\
\text { - } & 1.3 \text { LSH-134 alarm }\end{array}$ & 4 & 2 & $\mathrm{AC}$ & None \\
\hline & & 2. LT-106 failure & & - $\quad 2.1$ LSH-134 alarm & 4 & 3 & $\mathrm{AC}$ & None \\
\hline & & $\begin{array}{l}\text { 3. Oil line to } \\
\text { storage blocked }\end{array}$ & & $\begin{array}{ll}\text { - } & 3.1 \text { LSH-134 alarm } \\
\text { - } & \text { 3.2 High Level } \\
& \text { Alarm LT-106 }\end{array}$ & 4 & 3 & $\mathrm{AC}$ & None \\
\hline \multirow[b]{2}{*}{ Less } & $\begin{array}{l}\text { Lower level in V-102 } \\
\text { bottom }\end{array}$ & 4. LT-106 failure & $\begin{array}{ll}- & \text { Gas to storage } \\
\text { - } & \mathrm{H}_{2} \mathrm{~S} \text { release in the tanks }\end{array}$ & 4.1 PdT high alarm & 2 & 3 & 1 & $\begin{array}{l}\text { Install an LSL alarm } \\
\text { at V-102 }\end{array}$ \\
\hline & $\begin{array}{l}\text { Lower level in V-102 } \\
\text { chimney tray }\end{array}$ & $\begin{array}{l}\text { 5. Low oil input } \\
\text { to V-102 }\end{array}$ & $\begin{array}{ll}- & \text { No feed to E-101 } \\
\text { - } & \text { Poor crude stabilization }\end{array}$ & $\begin{array}{l}\text { 5.1 Crude from } \\
\text { LV-106 sampling } \\
\text { every } 4 \text { hours }\end{array}$ & 4 & 2 & $\mathrm{AC}$ & None \\
\hline
\end{tabular}


Table A2. The "Flow"-Element of "Node-5".

\begin{tabular}{|c|c|c|c|c|c|c|c|c|}
\hline Node & 5 & & & & & & & \\
\hline Element & Flow & & & & & & & \\
\hline \multirow{2}{*}{ Guideword } & \multirow{2}{*}{ Deviation } & \multirow{2}{*}{ Possible Cause } & \multirow{2}{*}{ Consequences } & \multirow{2}{*}{ Safeguards } & \multicolumn{3}{|c|}{ Risk Matrix } & \multirow{2}{*}{ Recommendations } \\
\hline & & & & & $\mathrm{s}$ & L & $\mathbf{R}$ & \\
\hline \multirow[t]{3}{*}{ More } & $\begin{array}{l}\text { More crude-oil input } \\
\text { flow }\end{array}$ & 6. FV-107 bypass open & $\begin{array}{l}\text { Poor crude stabilization } \\
\text { - }\end{array}$ & None & 4 & 4 & NSR & None \\
\hline & \multirow[t]{2}{*}{$\begin{array}{l}\text { More crude vapors } \\
\text { output from E-101 }\end{array}$} & $\begin{array}{l}\text { 7. Increased temperature } \\
\text { in E-101 }\end{array}$ & \multirow{2}{*}{$\begin{array}{ll}- & \text { Pressure increase } \\
- & \text { Pipeline fracture } \\
- & \mathrm{H}_{2} \mathrm{~S} \text { release } \\
- & \text { Oil spill } \\
- & \text { Fire Hazard } \\
- & \text { Explosion Hazard }\end{array}$} & $\begin{array}{ll}- & 7.1 \mathrm{PSV}-108 / 109 \\
& \text { will open } \\
- & 7.1 \mathrm{H}_{2} \mathrm{~S} \text { alarm } \\
- & 7.2 \text { Explosive alarm }\end{array}$ & 2 & 3 & 1 & None \\
\hline & & $\begin{array}{l}\text { 8. High volatility oil from } \\
\text { platform }\end{array}$ & & & 2 & 4 & $\mathrm{AC}$ & None \\
\hline & $\begin{array}{l}\text { More steam flow to } \\
\text { E-101 }\end{array}$ & 9. TT-101A/B Failure & $\begin{array}{ll}- & \text { Damage to E-101 } \\
- & \text { Loss of non-volatile } \\
\text { hydrocarbons } \\
\text { through V-103. } \\
\text { - Increased } \\
\text { steam consumption }\end{array}$ & None & 4 & 3 & $\mathrm{AC}$ & $\begin{array}{l}\text { Install TSH alarm in } \\
\text { E-101 vapor exit }\end{array}$ \\
\hline & \multirow[t]{2}{*}{$\begin{array}{l}\text { More gas flow to } \\
\text { V-103 }\end{array}$} & $\begin{array}{l}\text { 10. High } \mathrm{H}_{2} \mathrm{~S} \text { content of } \\
\text { oil }\end{array}$ & $\begin{array}{ll}- & \text { Pressure increase } \\
- & \text { Pipeline fracture } \\
- & \mathrm{H}_{2} \mathrm{~S} \text { release } \\
- & \text { Oil spill } \\
- & \text { Fire Hazard } \\
- & \text { Explosion Hazard }\end{array}$ & $\begin{array}{ll}\text { - } & 9.1 \mathrm{PSV}-210 / 211 \\
& \text { will open } \\
\text { - } & 9.2 \mathrm{PV}-103 \mathrm{~B} \text { will } \\
\text { open to flare } \\
-\quad & 9.3 \mathrm{H}_{2} \mathrm{~S} \text { alarm } \\
- & 9.4 \text { Explosive alarm }\end{array}$ & 2 & 4 & $\mathrm{AC}$ & None \\
\hline & & $\begin{array}{l}\text { 11. Excessive vapor } \\
\text { production in E-101 }\end{array}$ & $\begin{array}{ll}- & \text { Pressure increase } \\
- & \text { Loss of non-volatile } \\
& \text { hydrocarbons } \\
\text { through V-103 } \\
- & \text { Pipeline fracture } \\
- & \mathrm{H}_{2} \mathrm{~S} \text { release } \\
- & \text { Oil spill } \\
- & \text { Fire Hazard } \\
- & \text { Explosion Hazard }\end{array}$ & $\begin{array}{ll}\text { - } & \text { 10.1 PSV-210/211 } \\
\text { - } & \text { will open } \\
& \text { 10.2 PV-103B will } \\
\text { open to flare } \\
\text { - } & 10.3 \mathrm{H}_{2} \mathrm{~S} \text { alarm } \\
- & 10.4 \\
& \text { Explosive alarm } \\
\text { - } & \text { 10.5 PdT alarm }\end{array}$ & 2 & 3 & 1 & None \\
\hline
\end{tabular}


Table A2. Cont.

\begin{tabular}{|c|c|c|c|c|c|c|c|c|}
\hline Node & 5 & & & & & & & \\
\hline Element & Flow & & & & & & & \\
\hline \multirow{2}{*}{ Guideword } & \multirow{2}{*}{ Deviation } & \multirow{2}{*}{ Possible Cause } & \multirow{2}{*}{ Consequences } & \multirow{2}{*}{ Safeguards } & \multicolumn{3}{|c|}{ Risk Matrix } & \multirow{2}{*}{ Recommendations } \\
\hline & & & & & $\mathrm{S}$ & L & $\mathbf{R}$ & \\
\hline \multirow{6}{*}{ Less } & \multirow{2}{*}{$\begin{array}{l}\text { Less crude-oil input } \\
\text { flow }\end{array}$} & $\begin{array}{l}\text { 12. Low oil flow from } \\
\text { platform }\end{array}$ & $\begin{array}{l}\text { - Column disks not } \\
\text { working properly. }\end{array}$ & \multirow{5}{*}{$\begin{array}{l}\text { 12.1 Crude from } \\
\text { LV-106 sampling } \\
\text { every } 4 \text { hours }\end{array}$} & 4 & 2 & AC & None \\
\hline & & 13. FT-107 failure & - $\quad$ Poor stabilization & & 4 & 3 & $\mathrm{AC}$ & None \\
\hline & \multirow{2}{*}{$\begin{array}{l}\text { Less crude-oil vapors } \\
\text { output flow from } \\
\text { E-101 }\end{array}$} & 14. TT-101 failure & \multirow{3}{*}{ Poor stabilization } & & \multirow{3}{*}{3} & \multirow{3}{*}{3} & \multirow{3}{*}{$\mathrm{AC}$} & $\begin{array}{l}\text { Install TSL alarm at } \\
\text { E-101 vapor output }\end{array}$ \\
\hline & & $\begin{array}{l}\text { 15. Non-volatile oil from } \\
\text { platform }\end{array}$ & & & & & & None \\
\hline & $\begin{array}{l}\text { Less steam flow to } \\
\text { E-101 }\end{array}$ & 16. TT-101 failure & & & & & & None \\
\hline & $\begin{array}{l}\text { Less stabilized oil } \\
\text { flow to P-101 }\end{array}$ & $\begin{array}{l}\text { 17. Low oil flow from } \\
\text { platform }\end{array}$ & Pump cavitation & None & 4 & 3 & $\mathrm{AC}$ & $\begin{array}{l}\text { Install a FSL alarm at } \\
\text { P-101 suction }\end{array}$ \\
\hline Reverse & $\begin{array}{l}\text { Reverse flow of gas to } \\
\text { FV-107 }\end{array}$ & 18. Pipeline fracture & $\begin{array}{ll}- & \text { Pipeline fracture } \\
- & \mathrm{H}_{2} \mathrm{~S} \text { release } \\
- & \text { Oil spill } \\
- & \text { Fire Hazard } \\
- & \text { Explosion Hazard }\end{array}$ & $\begin{array}{ll}- & 18.1 \mathrm{H}_{2} \mathrm{~S} \text { alarm } \\
- & 18.2 \\
& \text { Explosive alarm }\end{array}$ & 2 & 4 & $\mathrm{AC}$ & None \\
\hline \multirow{6}{*}{ No } & $\begin{array}{l}\text { No crude-oil input } \\
\text { flow }\end{array}$ & $\begin{array}{l}\text { 19. No oil flow from } \\
\text { platform }\end{array}$ & No production & 19.1 PSL-120 alarm & 4 & 3 & $\mathrm{AC}$ & None \\
\hline & \multirow{3}{*}{$\begin{array}{l}\text { No steam flow to } \\
\text { E-101 }\end{array}$} & 20. FT-110 Failure & No crude stabilization & $\begin{array}{l}20.1 \text { TR-201 will } \\
\text { record the } \\
\text { temperature drop }\end{array}$ & 3 & 3 & $\mathrm{AC}$ & $\begin{array}{l}\text { Install a TSL alarm at } \\
\text { E-101 vapor exit }\end{array}$ \\
\hline & & $\begin{array}{l}\text { 21. Steam production } \\
\text { facility failure }\end{array}$ & & None & 3 & 4 & $\mathrm{AC}$ & None \\
\hline & & 22. Blocked E-101 tubes & & 22.1 Spare E-101 & 3 & 3 & $\mathrm{AC}$ & None \\
\hline & \multirow[t]{2}{*}{$\begin{array}{l}\text { No stabilized crude } \\
\text { flow }\end{array}$} & 23. P-101 shutdown & \multirow[t]{2}{*}{ No Production } & $\begin{array}{ll}- & \text { 23.1 PSL-120 } \\
\text { - } & \text { P-101 Discharge } \\
\text { 23.2 Spare P-101 }\end{array}$ & 4 & 3 & $\mathrm{AC}$ & None \\
\hline & & $\begin{array}{l}\text { 24. Pipeline to storage } \\
\text { blocked }\end{array}$ & & None & 4 & 3 & $\mathrm{AC}$ & None \\
\hline
\end{tabular}


Table A3. The "Pressure"-Element of "Node-5".

\begin{tabular}{|c|c|c|c|c|c|c|c|c|}
\hline Node & 5 & & & & & & & \\
\hline Element & Pressure & & & & & & & \\
\hline \multirow{2}{*}{ Guideword } & \multirow{2}{*}{ Deviation } & \multirow{2}{*}{ Possible Cause } & \multirow{2}{*}{ Consequences } & \multirow{2}{*}{ Safeguards } & \multicolumn{3}{|c|}{ Risk Matrix } & \multirow{2}{*}{ Recommendations } \\
\hline & & & & & $\mathrm{s}$ & $\mathbf{L}$ & $\mathbf{R}$ & \\
\hline \multirow{6}{*}{ More } & $\begin{array}{l}\text { More pressure in } \\
\text { crude input line }\end{array}$ & $\begin{array}{l}\text { 25. Column tray disks } \\
\text { clogged }\end{array}$ & - No crude stabilization & None & 3 & 3 & $\mathrm{AC}$ & None \\
\hline & \multirow[t]{2}{*}{$\begin{array}{l}\text { More pressure in gas } \\
\text { line }\end{array}$} & 26. PT-103 failure & $\begin{array}{ll}- & \text { Pipeline fracture } \\
- & \mathrm{H}_{2} \mathrm{~S} \text { release } \\
- & \text { Oil spill } \\
- & \text { Fire Hazard } \\
- & \text { Explosion Hazard }\end{array}$ & $\begin{array}{ll}- & 26.1 \mathrm{PSV} 110 / 111 \\
& \text { will open to flare } \\
- & 26.2 \mathrm{H}_{2} \mathrm{~S} \text { alarm } \\
- & 26.3 \\
& \text { Explosive alarm }\end{array}$ & 2 & 3 & 1 & None \\
\hline & & 27. Line to V-103 blocked & $\begin{array}{ll}- & \text { Pipeline fracture } \\
- & \mathrm{H}_{2} \mathrm{~S} \text { release } \\
- & \text { Oil spill } \\
- & \text { Fire Hazard } \\
- & \text { Explosion Hazard }\end{array}$ & 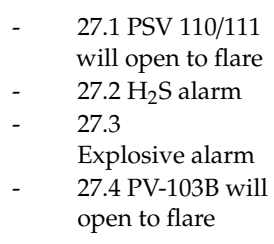 & 3 & 3 & $\mathrm{AC}$ & None \\
\hline & $\begin{array}{l}\text { More pressure in } \\
\text { pipeline to P-101 }\end{array}$ & 28. PT-103 Failure & $\begin{array}{ll}- & \text { Pump seal failure } \\
- & \text { Pipeline fracture } \\
- & \mathrm{H}_{2} \mathrm{~S} \text { release } \\
- & \text { Oil spill } \\
- & \text { Fire Hazard } \\
- & \text { Explosion Hazard }\end{array}$ & None & 3 & 3 & AC & None \\
\hline & \multirow[t]{2}{*}{$\begin{array}{l}\text { More pressure in } \\
\text { E-101 }\end{array}$} & $\begin{array}{l}\text { 29. Line from E-101 to } \\
\text { V-102 blocked }\end{array}$ & $\begin{array}{ll}\text { - } & \text { No crude stabilization } \\
- & \text { E-101 fracture } \\
- & \mathrm{H}_{2} \mathrm{~S} \text { release } \\
- & \text { Oil spill-Fire Hazard } \\
\text { - } & \text { Explosion Hazard }\end{array}$ & $\begin{array}{l}\text { 29.1 PSV-109 will } \\
\text { open to flare }\end{array}$ & 3 & 3 & $\mathrm{AC}$ & None \\
\hline & & 30. Steam to Crude leak & $\begin{array}{ll}\text { - } & \text { Increased V-102 pressure } \\
\text { - } & \text { Crude to storage increased } \\
& \text { water content }\end{array}$ & $\begin{array}{l}\text { - } \quad 30.1 \text { PSV-109 will } \\
\text { open to flare }\end{array}$ & 3 & 3 & $\mathrm{AC}$ & $\begin{array}{l}\text { During shutdown } \\
\text { check E-101 integrity }\end{array}$ \\
\hline
\end{tabular}


Table A3. Cont.

\begin{tabular}{|c|c|c|c|c|c|c|c|c|}
\hline Node & 5 & & & & & & & \\
\hline Element & Pressure & & & & & & & \\
\hline \multirow{2}{*}{ Guideword } & \multirow{2}{*}{ Deviation } & \multirow{2}{*}{ Possible Cause } & \multirow{2}{*}{ Consequences } & \multirow{2}{*}{ Safeguards } & \multicolumn{3}{|c|}{ Risk Matrix } & \multirow{2}{*}{ Recommendations } \\
\hline & & & & & $\mathrm{S}$ & L & $\mathbf{R}$ & \\
\hline \multirow{4}{*}{ Less } & \multirow[b]{2}{*}{$\begin{array}{l}\text { Less pressure in } \\
\text { crude input line }\end{array}$} & 31. PT-102 failure & No production & None & 4 & 3 & AC & None \\
\hline & & 32. Pipeline fracture & $\begin{array}{ll}- & \text { Pipeline fracture } \\
- & \mathrm{H}_{2} \mathrm{~S} \text { release } \\
- & \text { Oil spill } \\
- & \text { Fire Hazard } \\
- & \text { Explosion Hazard }\end{array}$ & $\begin{array}{ll}- & 32.2 \mathrm{H}_{2} \mathrm{~S} \text { alarm } \\
- & 32.3 \\
& \text { Explosive alarm }\end{array}$ & 2 & 4 & AC & None \\
\hline & $\begin{array}{l}\text { Less pressure in } \\
\text { pipeline to P-101 }\end{array}$ & 34. PT-102 failure & Pump Cavitation & None & 3 & 3 & $\mathrm{AC}$ & None \\
\hline & $\begin{array}{l}\text { Less pressure in gas } \\
\text { pipeline }\end{array}$ & 35. Pipeline fracture & $\begin{array}{ll}- & \text { Pipeline fracture } \\
- & \mathrm{H}_{2} \mathrm{~S} \text { release } \\
- & \text { Oil spill } \\
- & \text { Fire Hazard } \\
- & \text { Explosion Hazard }\end{array}$ & $\begin{array}{ll}- & 32.2 \mathrm{H}_{2} \mathrm{~S} \text { alarm } \\
- & 32.3 \\
& \text { Explosive alarm }\end{array}$ & 2 & 4 & AC & None \\
\hline
\end{tabular}

Table A4. The "Temperature"-Element of "Node-5".

\begin{tabular}{|c|c|c|c|c|c|c|c|c|}
\hline Node & 5 & & & & & & & \\
\hline Element & Temperature & & & & & & & \\
\hline \multirow{2}{*}{ Guideword } & \multirow{2}{*}{ Deviation } & \multirow{2}{*}{ Possible Cause } & \multirow{2}{*}{ Consequences } & \multirow{2}{*}{ Safeguards } & \multicolumn{3}{|c|}{ Risk Matrix } & \multirow{2}{*}{ Recommendations } \\
\hline & & & & & $\mathrm{S}$ & $\mathbf{L}$ & $\mathbf{R}$ & \\
\hline \multirow{3}{*}{ More } & \multirow{3}{*}{$\begin{array}{l}\text { Higher temperature } \\
\text { in E-101 exit }\end{array}$} & 36. FT-110 failure & \multirow{2}{*}{$\begin{array}{ll}\text { - } & \text { Steam waste } \\
\text { - } & \text { More hydrocarbon } \\
\text { evaporation and escape to } \\
\text { Sour Water }\end{array}$} & $\begin{array}{ll}\text { - } & 36.1 \text { TR will record } \\
& \text { temperature increase }\end{array}$ & 3 & 3 & $\mathrm{AC}$ & \multirow{3}{*}{$\begin{array}{c}\text { Install a TSH alarm a } \\
\text { E-101 output }\end{array}$} \\
\hline & & 37. TT-101 failure & & None & 3 & 3 & AC & \\
\hline & & $\begin{array}{l}\text { 38. Steam leakage to } \\
\text { crude in E-101 }\end{array}$ & $\begin{array}{ll}\text { - } & \text { Increased pressure in V-102 } \\
\text { - } & \text { Steam Waste }\end{array}$ & $\begin{array}{l}38.1 \text { PSV-109 } \\
\text { will open }\end{array}$ & 3 & 4 & $\mathrm{AC}$ & \\
\hline \multirow{2}{*}{ Less } & \multirow{2}{*}{$\begin{array}{l}\text { Low temperature in } \\
\text { E-101 exit }\end{array}$} & 39. FT-110 failure & \multirow[t]{2}{*}{ Poor Crude stabilization } & $\begin{array}{ll}- & 36.1 \mathrm{TR} \text { will record } \\
& \text { temperature increase }\end{array}$ & 3 & 3 & $\mathrm{AC}$ & None \\
\hline & & 40. TT-101 failure & & None & 3 & 3 & $\mathrm{AC}$ & None \\
\hline
\end{tabular}


Table A5. The "Composition"-Element of "Node-5".

\begin{tabular}{|c|c|c|c|c|c|c|c|c|}
\hline Node & 5 & & & & & & & \\
\hline Element & Composition & & & & & & & \\
\hline \multirow{2}{*}{ Guideword } & \multirow{2}{*}{ Deviation } & \multirow{2}{*}{ Possible Cause } & \multirow{2}{*}{ Consequences } & \multirow{2}{*}{ Safeguards } & \multicolumn{3}{|c|}{ Risk Matrix } & \multirow{2}{*}{ Recommendations } \\
\hline & & & & & $S$ & L & $\mathbf{R}$ & \\
\hline \multirow{4}{*}{ Other than } & \multirow{4}{*}{$\begin{array}{l}\text { Composition in } \\
\text { Crude to storage } \\
\text { other than required }\end{array}$} & $\begin{array}{l}\text { 41. Low steam flow to } \\
\text { E-101 }\end{array}$ & \multirow{4}{*}{ Increased $\mathrm{H}_{2} \mathrm{~S}$ in crude } & \multirow{3}{*}{$\begin{array}{l}\text { 41.1 Crude to } \\
\text { storage sampling }\end{array}$} & 3 & 3 & $\mathrm{AC}$ & $\begin{array}{l}\text { Install a TSL alarm in } \\
\text { E-101 output }\end{array}$ \\
\hline & & 42. Low crude input & & & 3 & 2 & 1 & None \\
\hline & & 43. High crude input & & & 3 & 4 & AC & None \\
\hline & & $\begin{array}{l}\text { 44.Asphaltenes on } \\
\text { Column disk }\end{array}$ & & $\begin{array}{ll}\text { - } & \text { 44.1 High Pressure } \\
& \text { differential PdT-140 }\end{array}$ & 3 & 3 & $\mathrm{AC}$ & None \\
\hline
\end{tabular}

Table A6. The "Containment"-Element of "Node-5".

\begin{tabular}{|c|c|c|c|c|c|c|c|c|}
\hline Node & 5 & & & & & & & \\
\hline Element & Containment & & & & & & & \\
\hline \multirow{2}{*}{ Guideword } & \multirow{2}{*}{ Deviation } & \multirow{2}{*}{ Possible Cause } & \multirow{2}{*}{ Consequences } & \multirow{2}{*}{ Safeguards } & \multicolumn{3}{|c|}{ Risk Matrix } & \multirow{2}{*}{ Recommendations } \\
\hline & & & & & $\mathrm{S}$ & $\mathbf{L}$ & $\mathbf{R}$ & \\
\hline \multirow[b]{2}{*}{ No } & \multirow{2}{*}{ No Containment } & 45. Fractured Vessel & \multirow{2}{*}{$\begin{array}{ll}- & \text { Oil spill } \\
- & \text { Sour water spill } \\
- & \mathrm{H}_{2} \mathrm{~S} \text { release } \\
- & \text { Fire hazard } \\
- & \text { Explosion hazard }\end{array}$} & \multirow{2}{*}{$\begin{array}{ll}- & 45.1 \mathrm{H}_{2} \mathrm{~S} \text { Alarm } \\
- & 45.2 \\
& \text { Explosives Alarm }\end{array}$} & \multirow[t]{2}{*}{2} & \multirow[t]{2}{*}{3} & \multirow[t]{2}{*}{1} & $\begin{array}{l}\text { Install a PSL alarm at } \\
\text { V-101 }\end{array}$ \\
\hline & & $\begin{array}{l}\text { 46. Valve opened to } \\
\text { atmosphere }\end{array}$ & & & & & & $\begin{array}{l}\text { Allow only qualified } \\
\text { personnel to operate } \\
\text { valves }\end{array}$ \\
\hline
\end{tabular}




\section{References}

1. Lees, F.P. Loss Prevention in the Process Industries: Hazard Identification, Assessment and Control; Reed: Oxford, UK, 1980.

2. Marhavilas, P.K.; Filippidis, M.; Koulinas, G.K.; Koulouriotis, D.E. The integration of HAZOP study with risk-matrix and the analytical-hierarchy process for identifying critical control-points and prioritizing risks in industry-A case study. J. Loss Prev. Process. Ind. 2019. [CrossRef]

3. Sultana, S.; Okoh, P.; Haugen, S.; Vinnem, J.E. Hazard analysis: Application of STPA to ship-to-ship transfer of LNG. J. Loss Prev. Process. Ind. 2019, 60, 241-252. [CrossRef]

4. Swann, C.; Preston, M. Twenty-five years of HAZOPs. J. Loss Prev. Process. Ind. 1995, 8, 349-353. [CrossRef]

5. Jagtman, H.; Hale, A.; Heijer, T. A support tool for identifying evaluation issues of road safety measures. Reliab. Eng. Syst. Saf. 2005, 90, 206-216. [CrossRef]

6. Ftenakis, V.M.; Trammell, S.R. Reference Guide for Hazard Analysis in PV Facilities. Available online: https://www.researchgate.net/publication/228611604_Reference_Guide_for_Hazard_Analysis_in_ PV_Facilities (accessed on 29 January 2020).

7. Chudleigh, M.F. Hazard analysis of a computer based medical diagnostic system. Comput. Methods Programs Biomed. 1994, 44, 45-54. [CrossRef]

8. Saaty, T.L. How to make a decision: The analytic hierarchy process. Eur. J. Oper. Res. 1994, 44, 45-54. [CrossRef]

9. Henderson, R.D.; Dutta, S.P. Use of the analytic hierarchy process in ergonomic analysis. Int. J. Ind. Ergon. 1990. [CrossRef]

10. Badri, A.; Nadeau, S.; Gbodossou, A. Proposal of a risk-factor-based analytical approach for integrating occupational health and safety into project risk evaluation. Accid. Anal. Prev. 2012, 48, 223-234. [CrossRef]

11. Aminbakhsh, S.; Gündüz, M.; Sonmez, R. Safety risk assessment using analytic hierarchy process (AHP) during planning and budgeting of construction projects. J. Saf. Res. 2013, 46, 99-105. [CrossRef]

12. Mayes, T.; Kilsby, D.C. The use of HAZOP hazard analysis to identify critical control points for the microbiological safety of food. Food Qual. Prefer. 1989, 1, 53-57. [CrossRef]

13. Alaei, R.; Mansoori, S.A.A.; Moghaddam, A.H.; Mansoori, S.M.; Mansoori, N. Safety assessment approach of hazard and operability (HAZOP) for sulfur recovery unit Claus reaction furnace package; blower; heat exchanger equipment in South Pars gas processing plant. J. Nat. Gas Sci. Eng. 2014, 20, 271-284. [CrossRef]

14. Othman, M.R.; Idris, R.; Hassim, M.H.; Ibrahim, W.H.W. Prioritizing HAZOP analysis using analytic hierarchy process (AHP). Clean Technol. Environ. Policy 2016, 18, 1345-1360. [CrossRef]

15. Cheraghi, M.; Baladeh, A.E.; Khakzad, N. A fuzzy multi-attribute HAZOP technique (FMA-HAZOP): Application to gas wellhead facilities. Saf. Sci. 2019, 114, 12-22. [CrossRef]

16. Koulinas, G.K.; Marhavilas, P.K.; Demesouka, O.E.; Vavatsikos, A.P.; Koulouriotis, D.E. Risk Analysis and Assessment in the worksites using the Fuzzy-Analytical Hierarchy Process and a Quantitative Technique-A case study for the Greek Construction sector. Saf. Sci. 2019. [CrossRef]

17. Koulinas, G.K.; Demesouka, O.E.; Marhavilas, P.K.; Vavatsikos, A.P.; Koulouriotis, D.E. Risk Assessment Using Fuzzy TOPSIS and PRAT for Sustainable Engineering Projects. Sustainability 2019, 11, 615. [CrossRef]

18. Marhavilas, P.K.; Koulouriotis, D.E.; Nikolaou, I.; Tsotoulidou, S. International Occupational Health and Safety Management-Systems Standards as a Frame for the Sustainability: Mapping the Territory. Sustainability 2018, 10, 3663. [CrossRef]

19. ICST\&D. In Proceedings of the International Conference on Sustainable Technology and Development, Shenzhen, China, 22-25 August 2020; Available online: https:/www.elsevier.com/events/conferences/ international-conference-on-sustainable-technology-and-development (accessed on 9 December 2019).

20. Marhavilas, P.; Koulouriotis, D. A combined usage of stochastic and quantitative risk assessment methods in the worksites: Application on an electric power provider. Reliab. Eng. Syst. Saf. 2012, 97, 36-46. [CrossRef]

21. Marhavilas, P.; Koulouriotis, D. Developing a new alternative risk assessment framework in the work sites by including a stochastic and a deterministic process: A case study for the Greek Public Electric Power Provider. Saf. Sci. 2012, 50, 448-462. [CrossRef]

22. Marhavilas, P.; Koulouriotis, D.; Spartalis, S. Harmonic analysis of occupational-accident time-series as a part of the quantified risk evaluation in worksites: Application on electric power industry and construction sector. Reliab. Eng. Syst. Saf. 2013, 112, 8-25. [CrossRef] 
23. Lawley, H.G. Operability Studies and Hazard Analysis. Chem. Eng. Prog. 1974, 4, 105-116.

24. Lawley, H.G. Size up plant hazards this way, hydrocarb. Process 1976, 55, 247-261.

25. CIA. A Guide to Hazard and Operability Studies; Imperial Chemical Industries and Chemical Industries Associations: London, UK, 1977.

26. Baybutt, P. On the completeness of scenario identification in process hazard analysis (PHA). J. Loss Prev. Process. Ind. 2018, 55, 492-499. [CrossRef]

27. Markowski, A.S.; Siuta, D. Fuzzy logic approach for identifying representative accident scenarios. J. Loss Prev. Process. Ind. 2018, 56, 414-423. [CrossRef]

28. Dallat, C.; Salmon, P.M.; Goode, N. Risky systems versus risky people: To what extent do risk assessment methods consider the systems approach to accident causation? A review of the literature. Saf. Sci. 2019, 119, 266-279. [CrossRef]

29. Baybutt, P. A critique of the Hazard and Operability (HAZOP) study. J. Loss Prev. Process. Ind. 2015, 33, 52-58. [CrossRef]

30. Animah, I.; Shafiee, M. Application of risk analysis in the liquefied natural gas (LNG) sector: An overview. J. Loss Prev. Process. Ind. 2020, 63, 103980. [CrossRef]

31. Baladeh, A.E.; Cheraghi, M.; Khakzad, N. A multi-objective model to optimal selection of safety measures in oil and gas facilities. Process Saf. Environ. 2019. [CrossRef]

32. Kletz, T. HAZOP and HAZAN: Identifying and Assesing Process Industy Hazards; Institution of Chemical Engineers: Rugby, UK; Sydney, Australia, 1999.

33. Andow, P.K. Improvement of Operator Reliability Using Expert Systems. Reliab. Eng. 1986, 14, 309-319. [CrossRef]

34. Mentzer, R.A.; Zhang, J.; Xu, W.; Mannan, M.S. Mannan, What Does "Safe" Look and Feel Like? J. Loss Prev. Process. Ind. 2014, 32, 265-275. [CrossRef]

35. Herbert, I.L. Learning the lessons-Retrospective HAZOPs. Soc. Pet. Eng. J. 2011. [CrossRef]

36. Baybutt, P. The role of people and human factors in performing process hazard analysis and layers of protection analysis. J. Loss Prev. Process. Ind. 2013, 26, 1352-1365. [CrossRef]

37. Frank, W.L.; Whittle, D.K. Revalidating Process Hazards Analyses; American Institute of Chemical Engineers: New York, NY, USA, 2001.

38. Center for Chemical Process Safety (CCPS). Guidelines for Process Safety Documentation; American Institute of Chemical Engineers (AICE): New York, NY, USA, 1995.

39. Qureshi, A. The role of hazard and operability study in risk analysis of major hazard plant. J. Loss Prev. Process. Ind. 1988, 1, 104-109. [CrossRef]

40. Center for Chemical Process Safety (CCPS). Layer of Protection Analysis-Simplified Process Risk Assessment; American Institute of Chemical Engineers: New York, NY, USA, 2001; ISBN 978-0-8169-0811-0.

41. Center for Chemical Process Safety (CCPS). Guidelines for Hazard Evaluation Procedures, 3rd ed.; American Institute of Chemical Engineers: New York, NY, USA, 2008.

42. European Process Safety Centre (EPSC). HAZOP: Guide to Best Practice; Institute of Chemical Engineers: Rugby, UK, 2000.

43. Dunjó, J.; Fthenakis, V.; Vílchez, J.A.; Arnaldos, J. Hazard and operability (HAZOP) analysis. A literature review. J. Hazard. Mater. 2009, 173, 19-32.

44. Macdonald, D.; Mackay, S. Practical HAZOPs, Trips and Alarms; Newnes: Oxford, UK, 2004.

45. Marhavilas, P.K. Risk Assessment Techniques in the Worksites of Occupational Health-Safety Systems with Emphasis on Industries and Constructions. Ph.D. Thesis, Department of Production and Management Engineering, Democritus University of Thrace, Xanthi, Greece, 2015. Available online: http://hdl.handle.net/ 10442/hedi/35612 (accessed on 28 November 2019).

46. Reniers, G.; Dullaert, W.; Ale, B.; Soudan, K. The use of current risk analysis tools evaluated towards preventing external domino accidents. J. Loss Prev. Process. Ind. 2005, 18, 119-126. [CrossRef]

47. IEC. Functional Safety: Safety Instrumented Systems for the Process Sector; IEC61511; International Electrotechnical Commission: Geneva, Switzerland, 2003.

48. AbdelGawad, M.; Fayek, A.R. Risk Management in the Construction Industry Using Combined Fuzzy FMEA and Fuzzy AHP. J. Constr. Eng. Manag. 2010, 136, 1028-1036. [CrossRef]

49. Zheng, G.; Zhu, N.; Tian, Z.; Chen, Y.; Sun, B. Application of a trapezoidal fuzzy AHP method for work safety evaluation and early warning rating of hot and humid environments. Saf. Sci. 2012, 50, 228-239. [CrossRef] 
50. Basahel, A.; Taylan, O. Using fuzzy ahp and fuzzy topsis approaches for assessing safety conditions at worksites in construction industry. Int. J. Saf. Secur. Eng. 2016, 6, 728-745. [CrossRef]

51. Pour, F.S.A.; Gheorghe, A. Risk assessment of oil and natural gas drilling process by employing fuzzy sets and analytical hierarchy process (AHP). In Proceedings of the 2017 International Annual Conference of the American Society for Engineering Management (ASEM), Huntsville, AL, USA, 18-21 October 2017; Available online: https://www.scopus.com/inward/record.uri?eid=2-s2.0-85040090723\&partnerID=40\& md5=78216ee82ff871e798e203527a169c2f (accessed on 29 January 2020).

52. Gul, M. A review of occupational health and safety risk assessment approaches based on multi-criteria decision-making methods and their fuzzy versions. Hum. Ecol. Risk Assessment: Int. J. 2018, 24, 1723-1760. [CrossRef]

53. Zhen, X.; Vinnem, J.E.; Peng, C.; Huang, Y. Quantitative risk modelling of maintenance work on major offshore process equipment. J. Loss Prev. Process. Ind. 2018, 56, 430-443. [CrossRef]

54. Fattahi, R.; Khalilzadeh, M. Risk evaluation using a novel hybrid method based on FMEA, extended MULTIMOORA, and AHP methods under fuzzy environment. Saf. Sci. 2018, 102, 290-300. [CrossRef]

55. Chang, D.-Y. Applications of the extent analysis method on fuzzy AHP. Eur. J. Oper. Res. 1996, 95, 649-655. [CrossRef]

56. Lamata, M.T. Ranking of alternatives with ordered weighted averaging operators. Int. J. Intell. Syst. 2004, 19, 473-482. [CrossRef]

57. Zimmermann, H.J. Fuzzy Set Theory—And Its Applications; Springer: Berlin, Germany, 2001.

58. Filippidis, M. Hazard and Operability Study of a Sour Crude-Oil Processing Plant; Department of Production and Management Engineering, Democritus University of Thrace (DUTH): Xanthi, Greece, 2017.

59. Høj, N.P.; Kroger, W. Risk analyses of transportation on road and railway from a European Perspective. Saf. Sci. 2002, 40, 337-357. [CrossRef]

60. ISO. ISO/IEC Guide 51, Safety Aspects-Guidelines for Their Inclusion in Standards. Available online: https://www.iso.org/standard/32893.html (accessed on 29 January 2019).

61. ISO. ISO/IEC Guide 73, Risk Management-Vocabulary. Available online: https://www.iso.org/standard/44651. html (accessed on 29 January 2019).

62. Chan, H.K.; Sun, X.; Chung, S.-H. When should fuzzy analytic hierarchy process be used instead of analytic hierarchy process? Decis. Support Syst. 2019, 125. [CrossRef]

63. Gul, M.; Guneri, A.F. A fuzzy multi criteria risk assessment based on decision matrix technique: A case study for aluminum industry. J. Loss Prev. Process. Ind. 2016, 40, 89-100. [CrossRef]

64. Guo, L.; Kang, J. An extended HAZOP analysis approach with dynamic fault tree. J. Loss Prev. Process. Ind. 2015, 38, 224-232. [CrossRef]

65. Ahn, J.; Chang, D. Fuzzy-based HAZOP study for process industry. J. Hazard. Mater. 2016, 317, $303-311$. [CrossRef]

66. Marhavilas, P.K.; Filippidis, M.; Koulinas, G.K.; Koulouriotis, D.E. An expanded HAZOP-study with fuzzy-AHP (XPA-HAZOP technique): Application in a sour crude-oil processing plant. Saf. Sci. 2020, 124, 104590. [CrossRef]

67. Zheng, X.; Liu, M. An overview of accident forecasting methodologies. J. Loss Prev. Process. Ind. 2009, 22, 484-491. [CrossRef]

(C) 2020 by the authors. Licensee MDPI, Basel, Switzerland. This article is an open access article distributed under the terms and conditions of the Creative Commons Attribution (CC BY) license (http://creativecommons.org/licenses/by/4.0/). 